\title{
Bibliography of Donald Evan McAllister
}

\author{
BRIAN W. COAD \\ Canadian Museum of Nature, Box 3443 Postal Station D, Ottawa, Ontario K1P 6P4
}

Coad, Brian W. 2010. Bibliography of Donald Evan McAllister. Canadian Field-Naturalist 124(4): 336-358.

Don McAllister wrote a wide variety of articles and books for scientific and popular outlets. He also served as the founder and editor of two journals, Sea Wind and Canadian Biodiversity (later named Global Biodiversity in 1993 and Biodiversity (Journal of Life on Earth) in 2000). This work attempts to be a bibliography but does not include numerous unpublished manuscript reports that Don submitted to the Canadian Museum of Nature, Ottawa and to other agencies.

Don published over 625 scientific papers, books, popular articles and book reviews in his career of 45 years from 1957 to 2002 . He averaged about 14 publications a year with book reviews numbering about 200 of the items listed here. His work ranged from such topics as systematic revisions of taxa to how to run a "green" school. The first 30 years of Don's publishing career was principally devoted to fishes, their systematics, ecology and conservation. The last 15 years were devoted mostly to biodiversity and conservation of natural resources through the founding of journals and his editorships of them and through lobbying efforts.

His ichthyological works were published primarily in English with some in French, mostly as translations of works originally in English. He shared authorship with over 110 separate collaborators but was first author on $90 \%$ of these papers.

The journals for which Don was the editor are listed for each issue. Minor notes, news items both short and long, press releases, annual reports, extracts of articles, quotations, notices of meetings and new books, indices, some short book reviews mostly listing contents of the book, editorial comments, comments on articles and some one page descriptions of species, were probably all authored by Don within these periodicals. These are not listed separately for space reasons but covered by the "Editor and partial author" statement (and it is not always clear that Don authored these unattributed notes, although generally he did). Significant articles and longer book reviews within these edited periodicals clearly authored by Don are listed separately - however the choice of these is necessarily selective and eclectic. The periodicals have numerous unnumbered figures as decoration and as watermarks as well as some that are part of articles, and some are repeated several times as decorative items. These are covered by the statement "numerous text figures" in the general listing by volume and issue.
A few articles are also available on the internet and were only seen in that format, or appear only there. Their URLs were all found in July 2001 and October 2003.

Dates in parentheses after volume number indicate the year of publication as marked on the paper but other evidence suggests the year after the author(s) is the correct one. Some articles, books and journals appeared in both English and French: these are not listed separately.

\# = not seen in original, or missing information.

McAllister, D. E. 1957. The systematics of the freshwater sculpins of British Columbia. M.A.thesis, Department of Zoology, University of British Columbia, Vancouver. 109 pages. 11 figures, 30 tables.

McAllister, Don E. 1959. Records of marine fishes from fresh water in British Columbia. Canadian Field-Naturalist 73(1): 13-14.

McAllister, D. E. 1959. Review of: The Freshwater Fishes of Canada by E. P. Slastenenko. Canadian Field-Naturalist 73(3): 181-182.

McAllister, D. E. 1960. Review of: The Angler's Book of Canadian Fishes by F. H. Wooding. Canadian Geographical Journal 60(1): V.

McAllister, D. E., and Sherman Bleakney. 1960. Some freshwater fishes from northeastern Quebec and Labrador. National Museum of Canada Bulletin 166, Contributions to Zoology 1958, Biological Series 61: 31-39, 1 figure, 5 tables.

McAllister, D. E. 1960. Review of: The Fresh-Water Fishes of British Columbia by G. Clifford Carl, W. A. Clemens, and C. C. Lindsey. Canadian Field-Naturalist 74(1): 55-56.

\#McAllister, Don E. 1960. Preliminary translation of keys of: [Observations on the eel-like lycodids [Lycenchelys Gill (Pisces, Zoarcidae) and related forms] in the seas of U.S.S.R. and neighbouring waters. Trudy Zoologicheskova Instituta Akademii Nauk SSSR 18: 349-384 by A. P. Andriashev 1955. Fisheries Research Board of Canada Translation Series 278: 1-4.

McAllister, D. E. 1960. List of the marine fishes of Canada. National Museum of Canada Bulletin 168, Biological Series, 62: iv + 76 pages, 1 table. 19 March.

McAllister, D. E. 1960. Keys to the marine fishes of Arctic Canada. Natural History Papers, National Museum of Canada 5: 1-21, 27 figures.

McAllister, D. E. 1960. Le Gasterosteus wheatlandi, nouvelle espèce de poisson pour la province de Québec. Le Naturaliste canadien 87(5): 117-118.

McAllister, D. E. 1960. A simple clamp to aid in counting fin rays. Copeia 1960(3): 250, 1 figure. 
McAllister, Don E. 1960. Sand-hiding behavior in young white hake. Canadian Field-Naturalist 74(4): 177, 1 figure.

McAllister, Don E. 1960. The twospine stickleback Gasterosteus wheatlandi new to the Canadian fresh-water fish fauna. Canadian Field-Naturalist 74(4): 177-178.

\#McAllister, Don E. 1961. Survey of Cottidae in Japan. A review of M. Watanabe: Cottidae (Pisces), Fauna Japonica. Progressive Fish-Culturist 23(1): 25.

McAllister, D. E. 1961. Review of: Fauna Japonica: Cottidae (Pisces) by Masao Watanabe. Canadian Field-Naturalist 75(1): 50.

McAllister, Don E. 1961. Fishes. Pages 131-135 in Methods of Collecting and Preserving Vertebrate Animals by R. M. National Museum of Canada Bulletin 69, Biological Series 18: 164 pages.

McAllister, D. E. 1961. Northward range extension of the flathead chub and trout-perch to Aklavik, N.W.T. Journal of the Fisheries Research Board of Canada 18(1): 141. 30 March

McAllister, D. E. 1961. Fish remains from a 600-year-old St. Lawrence River Iroquois site. National Museum of Canada Bulletin 172, Contributions to Zoology 1959, Biological Series 65: 34-38, 2 figures. 19 April

McAllister, D. E. 1961. A collection of oceanic fishes from off British Columbia with a discussion of the evolution of black peritoneum. National Museum of Canada Bulletin 172, Contributions to Zoology 1959, Biological Series 65: $39-43$.

McAllister, D. E. 1961. The origin and status of the deepwater sculpin, Myoxocephalus thompsonii, a Nearctic glacial relict. National Museum of Canada Bulletin 172, Contributions to Zoology 1959, Biological Series 65: 44-65, 3 figures, 6 tables.

McAllister, D. E., and C. C. Lindsey. 1961. Systematics of the freshwater sculpins (Cottus) of British Columbia. National Museum of Canada Bulletin 172, Contributions to Zoology 1959, Biological Series 65: 66-89, 5 figures, 10 tables.

McAllister, D. E., and R. J. Krejsa. 1961. Placement of the prowfishes, Zaproridae, in the superfamily Stichaeoidae. Natural History Papers, National Museum of Canada 11: 1-4. 24 July

McAllister, D. E. 1962. Fish remains from Ontario Indian sites 700 to 2500 years old. Natural History Papers, National Museum of Canada, 17: 1-6, 1 figure, 1 table. 27 August.

McAllister, D. E. 1962. Review of: Fishes of the Pacific Coast of Canada by W. A. Clemens and G. V. Wilby. Canadian Field-Naturalist 76(2): 117-118.

McAllister, Don E. 1962. The brassy minnow, river shiner and sauger new to Alberta. Canadian Field-Naturalist 76(2): 124-125.

McAllister, D. E. 1962. Fishes of the 1960 "Salvelinus" Program from western Arctic Canada. National Museum of Canada Bulletin 185, Contributions to Zoology 1962, Biological Series 69: 17-39, 4 figures.

Bousfield, E. L., and D. E. McAllister. 1962. Station list of the National Museum marine biological expedition to southeastern Alaska and Prince William Sound. National Museum of Canada Bulletin 183, Contributions to Zoology 1960-61, Biological Series 68: 76-103, 2 figures, 5 maps.

McAllister, D. E. 1963. Review of: The lake sturgeon, a history of its fishery and problems of conservation by W. J. K. Harkness and J. R. Dymond. Canadian Field-Naturalist 76(3) [1962]: 171.
McAllister, D. E. 1963. Review of: Silent Spring by Rachel Carson. Canadian Field-Naturalist 76(4) [1962]: 220-221.

McAllister, D. E. 1963. A revision of the smelt family, Osmeridae. National Museum of Canada Bulletin 191, Biological Series 71: iv +53 pages, 14 figures, 2 tables.

McAllister, D. E. 1963. Systematic notes on the sculpin genera Artediellus, Icelus, and Triglops on Arctic and Atlantic coasts of Canada. National Museum of Canada Bulletin 185, Contributions to Zoology Paper 4: 50-59, 8 figures, 3 tables. March

McAllister, Don E. 1963. The evolution of branchiostegals in teleostome fishes. American Society of Ichthyologists and Herpetologists, 50th Anniversary Meeting, Vancouver, British Columbia June 1963, page 46.

McAllister, D. E. 1963. Review of: Ichthyology by Karl F. Lagler, John E. Bardach and Robert R. Miller. Canadian Field-Naturalist 77(3): 171.

McAllister, D. E. 1963. Review of: Fishes of Ontario by H. H. MacKay. Canadian Field-Naturalist 77(4): 230.

McAllister, D. E. 1963. Fish remains from a 600-year-old Yukon archaeological site. Canadian Field-Naturalist 77(4): 232.

McAllister, Donald Evan. 1964. The evolution of branchiostegal rays in teleostome fishes. Ph.D. thesis, Department of Zoology, University of British Columbia, Vancouver. xii +483 pages., 3 figures, 18 plates.

McAllister, D. E. and E. I. S. Rees. 1964. A revision of the eelpout genus Melanostigma with a new genus and with comments on Maynea. National Museum of Canada Bulletin 199, Contributions to Zoology, Paper 5 (1963): 85-110, 9 figures, 3 tables.

McAllister, D. E. 1964. Dans l'Arctique... au bout du monde. Le Jeune Scientifique 3(1): 17-19, 4 figures.

McAllister, D. E. 1964. Distinguishing characters for the sculpins Cottus bairdii and C. cognatus in eastern Canada. Journal of the Fisheries Research Board of Canada 21(5): 1339-1342, 3 figures, 1 table.

McAllister, D. E. 1964. Fish collections from eastern Hudson Bay. Canadian Field-Naturalist 78(3): 167-178, 8 figures, 1 table.

McAllister, D. E. 1964. Review of: Fishes of the Western North Atlantic by H. B. Bigelow et al. Canadian FieldNaturalist 78(3): 194-195.

McAllister, D. E. 1964. Review of: Fish and Wildlife: A Memorial to W. J. K. Harkness, edited by J. R. Dymond. Canadian Field-Naturalist, 78(3): 195.

McAllister, D. E., and S. U. Qadri. 1965. Fish remains from a 2,500-year-old Lake Superior archaeological site, with notes on previous sites. Natural History Papers, National Museum of Canada 29: 1-8, 6 figures.

McAllister, D. E. 1965. Bibliography of Dr. Wilbert Amie Clemens. Institute of Fisheries, University of British Columbia, Museum Contribution 7: 1-12, portrait.

McAllister, D. E. 1965. Review of: Fishes Occurring in the Fresh Waters of Insular Newfoundland by W. B. Scott and E. J. Crossman. Canadian Field-Naturalist 79(1): 72-73.

McAllister, D. E. 1965. Distribution of freshwater fish in northern Canada. The Arctic Circular 16(2): 22-25.

McAllister, D. E. 1965. Review of: Fishes of the Western North Atlantic by H. B. Bigelow et al. Canadian FieldNaturalist 79(2): 148-149.

McAllister, D. E. 1965. Type specimens of fishes in the National Museum of Canada with brief historical notes. Natural History Papers, National Museum of Canada 31: 1-13, 2 figures. 
McAllister, D. E., and S. J. Westrheim. 1965. Widow rockfish, Sebastodes entomelas, new to British Columbia waters. Journal of the Fisheries Research Board of Canada 22(6): 1559-1561, 1 figure.

McAllister, D. E. 1966. The form and function of the lateral line in bony fishes. Proceedings of the Nineteenth Meeting of the Canadian Committee on Freshwater Fisheries Research, Appendix H, 1 page.

McAllister, D. E. 1966. Chapter VI. The collecting and preserving of fishes. Pages 152-170, figures 47-50, 1 unnumbered figure in Methods of Collecting and Preserving Vertebrate Animals by R. M. Anderson. 4th edition, revised. National Museum of Canada Bulletin, 69 (1965): vii + 199 pages, 53 figures.

McAllister, Don E. 1966. Bibliography of the marine fishes of Arctic Canada. Institute of Fisheries, University of British Columbia, Vancouver, Museum Contribution 8: 1-16.

McAllister, D. E. 1966. Review of: A Checklist of Canadian Atlantic Fishes with Keys for Identification by W. B. Scott and M. G. Scott. Canadian Field-Naturalist 80(1): 57-58.

McAllister, Don E. 1966. The significance of ventral bioluminescence in fishes in Bioluminescence in the Pacific. Proceedings of the Eleventh Pacific Science Congress, Tokyo, 1966. Volume 5, 1 page.

McAllister, D. E., and D. L. Dineley. 1966. Review of: Principles of Paleontology. Agnatha, Fishes, edited by D. V. Obruchev. Canadian Field-Naturalist 80(2): 112-113.

McAllister, D. E. 1966. Review of: Fishes of the Sea of Japan and neighbouring parts of the Okhotsk and Yellow Seas by G. U. Lindberg and M. I. Legeza. Canadian Field-Naturalist 80(2): 113.

McAllister, Don E. 1966. Numerical taxonomy and the smelt family, Osmeridae in Freshwater sciences and ichthyology. Proceedings of the Eleventh Pacific Science Congress, Tokyo, 1966. Volume 7, 1 page.

McAllister, D. E. 1966. Review of: Fishes of the Western North Atlantic, Part 5, Order Iniomi and Order Lyomeri by various authors. Canadian Field-Naturalist 80(3): 173-174.

McAllister, D. E. 1966. Review of: Catalogue Systématique des Noms de Genres de Poissons Actuels by Yves-J. Golvan. Canadian Field-Naturalist 80(3): 175.

McAllister, D. E. 1967. Numerical taxonomy and the smelt family, Osmeridae. Canadian Field-Naturalist 80(4) [1966]: 227-238, 2 figures, 4 tables.

Qadri, S. U., and D. E. McAllister. 1967. Fish remains from a 700-year-old southern Ontario archaeological site. Natural History Papers, National Museum of Canada 34: 1-6, 11 figures.

McAllister, D. E. 1967. The significance of ventral bioluminescence in fishes. Journal of the Fisheries Research Board of Canada 24(3): 537-554, 3 figures, 1 table.

McAllister, Don E. 1967. The significance of ventral bioluminescence in fishes. Science Report of the Yokusuka City Museum 13: 5-6. in: Symposium on bioluminescence in the Pacific area of the Eleventh Pacific Science Congress.

McAllister, Don E. 1967. The evolution of branchiostegals and associated opercular, gular, and hyoid bones, and the classification of teleostome fishes, living and fossil. Advance Abstracts of Contributions on Fisheries and Aquatic Sciences in India 1(3): 10-11.

McAllister, D. E. 1967. Review of Fishes of the Atlantic Coast of Canada by A. H. Leim and W. B. Scott. Canadian Field-Naturalist 81(3): 209-210.

McAllister, D. E. 1968. Review of: Freshwater Fishes of Eastern Canada by W. B. Scott. Canadian Field-Naturalist 81(4) [1967]: 296.
McAllister, D. E. 1968. Mandibular pore pattern in the sculpin family Cottidae. National Museum of Canada Bulletin 223. Contributions to Zoology IV: 58-69, 1 figure, 2 tables.

McAllister, D. E. 1968. The evolution of branchiostegals and associated opercular, gular, and hyoid bones, and the classification of teleostome fishes, living and fossil. National Museum of Canada Bulletin 221: xiv +239 pages, 3 figures, 21 plates, 2 tables, figured end papers.

McAllister, D. E. 1968. Review of: Modes of Reproduction in Fishes by Charles M. Breder, Jr. and Donn Eric Rosen. Canadian Field-Naturalist 82(1): 62-63.

McAllister, D. E. 1968. Northern field projects of the National Museum of Natural Sciences, 1968. The Arctic Circular 18(1/2): 33 .

McAllister, D. E. 1968. Poisonous and venomous fishes of Canada. Natural History Papers, National Museum of Canada 42: 1-11, 8 figures.

McAllister, D. E. 1968. A list of the fishes of the Ottawa area. Trail \& Landscape 2(6): 148-153, 2 photographs.

McAllister, D. E., et Claude Delisle. 1968. Le coelacanthe, un fossile vivant. Le Jeune Scientifique 7(2): 30-31, 3 figures.

Faber, Daniel J., and Don E. McAllister. 1968. Review of: Development of Fishes of the Chesapeake Bay Region. An Atlas of Egg, Larval, and Juvenile Stages by Alice J. Mansueti and Jerry D. Hardy. Canadian Field-Naturalist 82(2): 165-167.

McAllister, D. E. 1969. Review of: Freshwater Fishes of Connecticut by Walter R. Whitworth, Peter L. Berrien and Walter T. Keller. Canadian Field-Naturalist 82(4) [1968]: 301.

McAllister, D. E. 1969. Review of: Fishes of the Bahamas and Adjacent Tropical Waters by James E. Böhlke and Charles C. G. Chaplin. Canadian Field-Naturalist 82(4) [1968]: 301-302.

McAllister, D. E. 1969. Introduction of tropical fishes into a hotspring near Banff, Alberta. Canadian Field-Naturalist 83(1): 31-35, 2 figures, 1 table.

McAllister, D. E. 1969. Proposed activities of the National Museum of Natural Sciences, 1969. The Arctic Circular 19(2): 38-39.

McAllister, Don E. 1969. Systematic ichthyology. Memorial University of Newfoundland Marine Sciences Research Laboratory. Expert Advisory Group on Marine Sciences Research Needs in Newfoundland Waters, 26-31 August 1968. 3 pages. (Restricted distribution).

McAllister, Don E. 1969. Canada's fish fauna, pages 5354, 1 figure in: Animal Life in Canada Today. 1968 Canada Year Book. Queen's Printer, Ottawa. xvii + 1277 pages. [Les poissons du Canada. Dans: la faune actuel du Canada. L'Annuaire du Canada 1968. L'Imprimeur de la Reine, Ottawa].

McAllister, D. E., and C. R. Harington. 1969. Pleistocene grayling, Thymallus, from Yukon, Canada. Canadian Journal of Earth Sciences, 6(5): 1185-1190, 5 figures, 1 table.

\#McAllister, Don E. 1969. Un spécimen unique au Canada. Le Jeune Scientifique, 8(1): 25, photographs.

Bourne, Neil, and D. E. McAllister. 1970. The black hagfish, Eptatretus deani, from British Columbia. Journal of the Fisheries Research Board of Canada 26(12) [1969]: 3246-3248, 1 figure.

McAllister, D. E. 1970. Arctic activities of the National Museum of Natural Sciences, 1969 and 1970. The Arctic Circular 20(1): 17-18.

McAllister, D. E. 1970. Endangered wildlife - fish in Endangered wildlife in Canada. Canadian Wildlife Federation, 
Ottawa, pages 12, 15: 2 photographs/La faune en danger - poissons. Dans: La faune en danger au Canada. La Fédération canadienne de la Faune, Ottawa, pages 12, 15; 2 photographies.

McAllister, D. E. 1970. Review of: The Sockeye Salmon, Oncorhynchus nerka, by R. E. Foerster. Canadian FieldNaturalist 83(4) [1969]: 414-415.

McAllister, D. E. 1970. Review of L'Alose et le Gaspereau [The American Shad and the Alewife] by Jean-Marie Roy. Canadian Field-Naturalist 83(4) [1969]: 419.

McAllister, Don E. 1970. Review of: The structure and relationships of the paracanthopterygian fishes by Donn Eric Rosen and Colin Patterson. Copeia 1970(2): 400-401.

McAllister, D. E. 1970. Review of: The structure and relationships of the paracanthopterygian fishes by Donn Eric Rosen and Colin Patterson. Quarterly Review of Biology 45(2): 209

McAllister, D. E. 1970. Rare or endangered Canadian fishes. Canadian Field-Naturalist 84(1): 5-8.

McAllister, D. E. 1970. Review of: Checklist of Canadian Freshwater Fishes with Keys for Identification by W. B. Scott and E. J. Crossman. Canadian Field-Naturalist 84(1): 71-72. July 1970

McAllister, D. E. 1970. The fresh and brackish water fishes, Pages 38-43 in Fauna of Sable Island and its zoogeographic affinities. National Museum of Natural Sciences, Publications in Zoology 4: vi +45 pages, 1 table.

McAllister, D. E. 1970. Proposal for aquatic parks and reserves in Canada. Canadian Field-Naturalist 84(2): 97.

McAllister, D. E. 1970. Review of: Olfaction in Fishes by Herman Kleerekoper. Canadian Field-Naturalist 84(2): 197-198.

Waldman, M., and D. E. McAllister. 1970. Review of: Compléments à l'étude des Poissons Actinoptérygiens du Jurassique français by Sylvie Wenz. Canadian Field-Naturalist 84(3): 323-325.

McAllister, D. E. 1970. Review of: Catalogue des espèces de Poissons déposés au Musée de la Station de biologie marine de Grande-Rivière (Gaspé-sud) 1932-1969 by Julien Bergeron and Vianney Legendre. Canadian Field-Naturalist 84(3): 327.

McAllister, D. E. 1971. Introduction of tropical fishes into a hotspring near Banff, Alberta. OVAS (Ottawa Valley Aquarium Society) News 1971: 10-14, 2 figures (reprint of 1969 paper).

McAllister, D. E. 1971. Old fourlegs, a "living fossil", an account of the coelacanth fish, Latimeria chalumnae. National Museums of Canada, National Museum of Natural Sciences, Odyssey Series 1: 1-25, 4 figures, 7 plates. Le vieux quadrupède, «Fossile vivant ", présentation du coelacanthe, Latimeria chalumnae. Musée nationaux du Canada, Musée national des Sciences naturelles, Collection Odyssée 1: 1-25, 4 figures, 7 planches.

McAllister, D. E. 1971. Review of: A List of Common and Scientific Names of Fishes from the United States and Canada by R. M. Bailey et al.. Canadian Field-Naturalist 85(1): 85.

McAllister, D. E. 1971. Review of: Atlas and Gazetteer of Canada/Atlas et Toponymie du Canada by Department of Energy, Mines and Resources. Canadian Field-Naturalist 85(3): 275.

McAllister, Don E. 1971. Review of: Dean Bibliography of Fishes 1968 by James W. Atz. Canadian Field-Naturalist 85(3): 275-276.
McAllister, D. E. 1971. Iowa darters (Etheostoma exile) spawning at Lac la Peche, Quebec. Trail \& Landscape 5(4): 112-113, 2 photographs.

McAllister, D. E. 1972. Review of: Above and Below, a Journey through our National Underwater Parks by Helga Sandburg and George Crile, Jr. Canadian Field-Naturalist 85(4) [1971]: 343-344.

McAllister, D. E., and J. C. Ward. 1972. The deepwater sculpin, Myoxocephalus quadricornis thompsoni, new to Alberta, Canada. Journal of the Fisheries Research Board of Canada 29(3): 344-345.

McAllister, Don E. 1972. FIR [Fish Information Retrieval]. Mudpie (Museum and University Data, Program and Information Exchange) 25:3.

McAllister, Don E., Pierre Jolicoeur, and Hiroshi Tsuyuki. 1972. Morphological and myogen comparison of johnny and tessellated darters and their hybrids, genus Etheostoma, near Ottawa, Canada. Journal of the Fisheries Research Board of Canada 29(8): 1173-1180, 5 figures, 5 tables.

McAllister, Don E., Anton B. Leere, and Satya P. Sharma. 1972. A batch process computer information retrieval and cataloguing system in the fish collection, National Museum of Natural Sciences. Syllogeus, 1:1-20, 5 figures.

Brassard, Léo, et Don E. McAllister. 1972. Nouvelle capture du laimargue, Somniosus microcephalus (Bloch and Schneider), dans le Fjord du Saguenay. Le Naturaliste canadien 99(4): 441-442, 1 figure.

McAllister, Don E. 1972. Review of: Freshwater Fishes of Northwestern Canada and Alaska by J. D. McPhail and C. C. Lindsey. Canadian Field-Naturalist 86(1): 103-105.

McAllister, Don E. 1972. Review of: Kamloops, an angler's study of the Kamloop's trout by Steve Raymond. Canadian Field-Naturalist, 86(4): 409-410.

McAllister, Don E. 1972. Review of: The Fisherman's Handbook: A Complete Guide to Fishing in North America by John Power and Jeremy Brown. Canadian Field-Naturalist 87(1): 83-84.

McAllister, Don E. 1972. Review of: Freshwater Fishes of Manitoba, checklist and keys by Alex N. Fedoruk. Canadian Field-Naturalist, 87(1): 84 .

Gruchy, I. M., and Don E. McAllister. 1973. A bibliography of the smelt family, Osmeridae. Fisheries Research Board of Canada Technical Report 368 [1972]: ii + 104 pages.

McAllister, Don E. 1973. Variation in midlateral scale number in teleostome fishes. Program of the 53rd Annual Meeting of the American Society of Ichthyologists and Herpetologists, 24 June - 30 June, 1973, University of Costa Rica, San Jose. Supplement: Abstracts, 2 pages.

Kljukanov, V. A., and D. E. McAllister. Osmeridae, Pages 158-159 in J. C, Hureau and Th. Monod. Editors. Clofnam. Check-list of the fishes of the north-eastern Atlantic and of the Mediterranean/Catalogue des poissons de l'Atlantique du nord-est et de la Méditerranée. UNESCO, Paris. Volume I: xxii + 683 pages.

\#McAllister, Don E., Anton B. Leere, and Satya P. Sharma. 1973. A batch process computer information retrieval and cataloguing system in the fish collection, National $\mathrm{Mu}-$ seum of Natural Sciences. Decuscope 12(1): 5-13, 5 figures.

McAllister, D. E., and E. J. Crossman. 1974. A Guide to the Freshwater Sport Fishes of Canada. National Museums of Canada, National Museum of Natural Sciences, Natural History Series 1: xi +89 pages, 15 plates. Poisson de pêche sportive d'eau douce du Canada. Musées Nationaux du Canada, Musée national des Sciences naturelles, 1: xi + 91 pages. 15 planches. [dated 1973]. 
Bleakney, J. S., and Don E. McAllister. 1974. Fishes stranded during extreme low tides in Minas Basin, Nova Scotia. Canadian Field-Naturalist 87(4) [1973]: 371-376, 4 figures, 1 table.

McAllister, Don E., and C. G. Gruchy. 1974. Review of: Freshwater Fishes of Canada by W. B. Scott and E. J. Crossman. Canadian Field-Naturalist 88(2): 241-242.

Gorham, Stanley W., and Don E. McAllister. 1974. The shortnose sturgeon, Acipenser brevirostrum, in the Saint John River, New Brunswick, Canada, a rare and possibly endangered species. Syllogeus 5: 1-18, 5 figures, 2 tables.

McAllister, Don E., and Francis R. Cook, Editors. 1974. Programme de la $54^{\mathrm{e}}$ réunion annuelle de la Société Américaine d'Ichthyologie et de Herpétologie/Program of the 54th Annual Meeting of the American Society of Ichthyologists and Herpetologists, Musée National des Sciences Naturelles/National Museum of Natural Sciences, 17 June to 22 June/du 17 au 22 juin 1974, Ottawa. 18+38+18 pages.

McAllister, Don E. 1974. Zoogeography of the marine fishes of Arctic Canada. Programme de la $54^{\mathrm{e}}$ réunion annuelle de la Société Américaine d'Ichthyologie et de Herpétologie/Program of the 54th Annual Meeting of the American Society of Ichthyologists and Herpetologists, Musée National des Sciences Naturelles/National Museum of Natural Sciences, 17 June to 22 June/du 17 au 22 juin 1974, Ottawa, page 22 [abstract].

McAllister, Don E., Brian W. Coad, Peter Rubec, and Jadwiga Aniskowicz. 1974. Fishes of Canada's National Capital Region/Poissons de la region de la capitale du Canada. Programme de la $54^{\mathrm{e}}$ réunion annuelle de la Société Américaine d'Ichthyologie et de Herpétologie/Program of the 54th Annual Meeting of the American Society of Ichthyologists and Herpetologists, Musée National des Sciences Naturelles/National Museum of Natural Sciences, 17 June to 22 June/du 17 au 22 juin 1974, Ottawa, pages. 12-13 [abstract\}.

McAllister, Don E. 1974. Review of: Hydrographic history and relict fishes of the North-central Great Basin by Carl L. Hubbs, Robert Rush Miller and Laura C. Hubbs. Journal of the Fisheries Research Board of Canada 31(9): 1561.

McAllister, Don E, and Brian W. Coad. 1975. Fishes of Canada's National Capital Region/Poissons de la région de la capitale du Canada. Fisheries Research Board of Canada, Miscellaneous Special Publication, 24 [1974]: 1200, 87 illustrations, (9 colour), 4 figures, 77 maps. [Excerpts published in Trail \& Landscape: Introduction 9(4) [1975]: 117-121, 2 figures; Mooneye Hiodon tergisus Le Sueur 9(5) [1975]: 146-147, 2 figures; Lake Charr (trout) Salvelinus namayoush (sic) (Walbaum) 10(1) [1976]: 2021, 2 figures; Longnose dace Rhinichthys cataractae (Valenciennes) 10(2) [1976]: 42-43, 2 figures; Tadpole madtom Noturus gyrinus (Mitchill) 10(3) [1976]: 56-57, 2 figures; Brook stickleback Culaea inconstans (Kirtland) 10(4) [1976]: 90-91, 2 figures; Common shiner Notropis cornutus (Mitchill) 10(5) [1976]: 118-119, 2 figures).

Legendre, Vianney, J. G. Hunter, and Don E. McAllister. 1975. French, English and scientific names of marine fishes of Arctic Canada/Noms français, anglais et scientifiques des poissons marins de 1'Arctique canadien. Syllogeus 7: 1-15, 1 figure, 1 map.

McAllister, D. E. 1975. Review of: The Urohyal in Fishes by Takaya Kusaka. Journal of the Fisheries Research Board of Canada 32(2): 325.
Gruchy, C. G., and D. E. McAllister. 1975. Review of: Pacific Fishes of Canada by J. L. Hart. Canadian FieldNaturalist 89(1): 93-94.

McAllister, Don E. 1975. Review of: Interrelationships of Fishes, edited by P. H. Greenwood, R. S. Miles, and Colin Patterson. Transactions of the American Fisheries Society 104(2): 427-428.

McAllister, Don E. 1975. Fish collections from the Otish Mountain region, central Québec, Canada. Syllogeus 8: 112, 1 figure, 1 table.

McAllister, Don E., and John E. Randall. 1975. A new species of centrolophid fish from Easter Island and Rapa Iti Island in the South Pacific. National Museum of Natural Sciences, National Museums of Canada, Publications in Biological Oceanography, 8: ix +6 pages. 3 figures, 1 table.

McAllister, Don E. 1975. The compleat museum minicomputer cataloguing and research system. Program of the American Society of Ichthyologists and Herpetologists, 55th Annual Meeting, June 8-14, 1975, Williamsburg, Virginia. page 102 [abstract].

McAllister, Don E. 1975. A traction function in swimming for fish scales. Program of the American Society of Ichthyologists and Herpetologists, 55th Annual Meeting, June 814, 1975, Williamsburg, Virginia. page 103 [abstract].

McAllister, Don E. 1975. Scale number variation in teleostome fishes. Thirteenth Pacific Science Congress, Record of the Proceedings, Vancouver, Volume 1: 59 [abstract].

\#McAllister, Don E. 1975. The ecology of the marine fishes of Arctic Canada, page 33 [abstract] in Proceedings of the Circumpolar Conference on Northern Ecology, September 15-18, 1975, Ottawa.

McAllister, Don E. 1975. A new species of Arctic eelpout, Lycodes sagittarius, from the Beaufort Sea, Alaska, and the Kara Sea, USSR (Pisces: Zoarcidae). National Museum of Natural Sciences, National Museums of Canada, Publications in Biological Oceanography 9: 1-16, 3 figures, 2 tables.

Gilhen, John, C. G. Gruchy, and Don E. McAllister. 1976. The sheepshead, Archosargus probatocephalus, and the feather blenny, Hypsoblennius hentzi, two additions to the Canadian Atlantic ichthyofauna. Canadian Field-Naturalist 90(1): 42-46, 2 figures, 1 table.

McAllister, Don E., and Jadwiga Aniskowicz. 1976. Vertebral number in North American sculpins of the Myoxocephalus quadricornis-complex. Journal of the Fisheries Research Board of Canada 33(12): 2792-2799, 3 figures, 2 tables.

McAllister, Don E. 1976. Review of: Opération coelacanthe by Jean Anthony. Canadian Field-Naturalist 90(4): 511-512.

McAllister, D. E. 1977. Ecology of the marine fishes of Arctic Canada, pages II49-II65, 2 figures in Proceedings of the Circumpolar Conference on Northern Ecology, September 15-18, 1975, National Research Council of Canada, Ottawa. Section II, Marine Ecology. viii +648 pages.

McAllister, Don E., and C. G. Gruchy. 1977. Status and habitat of Canadian fishes in 1976, pages 151-157, 5 figures, in T. Mosquin and C. Suchal. Editors. Proceedings of the Symposium on Canada's Threatened Species and Habitats. Canadian Nature Federation, Special Publication, Ottawa, 6: 1-185.

McAllister, Don E., and Brian W. Coad. 1977. A test evaluating phenetic and cladistic relationships of Nearctic genera of Cyprinidae. Program of the American Society of 
Ichthyologists and Herpetologists, 57th Annual Meeting, 19-25 June 1977, Gainesville, Florida. 2 pages [abstract].

McAllister, D. E., and A. P. Andriashev. 1977. Ophidium parrii Ross, 1826 (Pisces); application for suppression Z.N.(S.) 1578. Bulletin of Zoological Nomenclature 34(1): 58-60.

McAllister, Don E. 1977. Review of: Opération coelacanthe par J. Anthony. Le Naturaliste canadien 103(5): 491-492.

McAllister, Don E. 1977. Review of: Répartition géographique des poissons, leur abondance relative et bathymétrie de la région du Lac Saint-Pierre by Gérard Massé et Jean-René Mongeau; Cartes de répartition géographique des espèces de poissons au sud du Québec, d'après les inventaires ichthyologiques effectués de 1963 à 1972 by Jean-René Mongeau; Les poissons de la région de Montréal, la pêche sportive et commerciale, les ensemencements, les frayères, la contamination par le mercure et les PCB by Jean-René Mongeau et Gérard Massé. Canadian FieldNaturalist 91(3): 330.

McAllister, Don E. 1977. Review of: Méthodes de pêche expérimentale, en eau douce, à l'usage du biologiste et du technicien de la faune by Jean-René Mongeau. Canadian Field-Naturalist 91(3): 330.

McAllister, Don E. 1977. Review of: The Anatomy of Fishes. Parts I and II by Wilhelm Harder. Canadian FieldNaturalist 91(3): 331.

McAllister, Don E., Robert Murphy, and John Morrison. 1978. The compleat minicomputer cataloging and research system for a museum. Curator 21(1): 63-91, 14 figures, 3 tables.

McAllister, Don E., et C. Lavett Smith. 1978. Mensuration morphologiques, dénombrements méristiques et taxonomie du coelacanthe, Latimeria chalumnae. Le Naturaliste canadien 105(2): 63-76, 10 figures, 3 tableaux.

Copeman, Douglas G., and Donald E. McAllister. 1978. Analysis of the effect of transplantation on morphometric and meristic characters in lake populations of the rainbow smelt, Osmerus mordax (Mitchill). Environmental Biology of Fishes 3(3): 253-259, 4 figures, 1 table.

McAllister, Don E., R. Murphy, et J. Morrison. 1978. Méthodes modernes de gestion et d'exploitation des collections. Revue de Travaux de l'Institut Scientifique et Technique des Pêches maritimes,40(3 et 4) [1976]:461480, 9 figures, 1 tableau.

McAllister, Don E., and Brian W. Coad. 1978. A test between relationships based on phenetic and cladistic taxonomic methods. Canadian Journal of Zoology 56(10): 2198-2210, 2 figures, 1 table.

\#McAllister, Don E., and Douglas G. Copeman. 1978. The effects of lake transplantation on morphometric and meristic characters in the rainbow smelt, Osmerus mordax (Mitchill). Newsletter/Bulletin of the Canadian Society of Environmental Biologists (Proceedings of the 19th Annual Meeting, January 4-6, 1978) 35(2): 45.

Andriashev, A. P., and Don E. McAllister. 1978. Status of the presumed zoarcid fish Ophidium parrii and its identity with Liparis koefoedi, Liparidae. Copeia, 1978(4): 710-712, 1 figure.

McAllister, Nancy, and Don E. McAllister. 1979. Review of: Précis de Zoologie: vertébrés. 2. Reproduction, biologie, évolution et systématique. Agnathes, poissons, amphibiens et reptiles by Pierre-P. Grassé. Canadian Field-Naturalist 92(4) [1978]: 410.
McAllister, Don E. 1979. Review of "Lexique anglaisfrançais, Termes techniques à l'Usage des Biologistes" by Jean Vaillancourt. Canadian Field-Naturalist 93(2): 208.

McAllister, Don E. 1979. Measuring device extends beyond fish. Canadian Research 12(7): 9, 13.

McAllister, D. E., and C. G. Gruchy. 1979. Status and habitat of Canadian fishes. International Wildlife 9(2): 28A$28 \mathrm{H}$ [insert: Wildlife Report. The Canadian Scene].

Faber, Daniel J., and Don E. McAllister, 1979. Review of: Development of Fishes of the Mid-Atlantic Bight. An Atlas of egg, larval and juvenile stages. Journal of the Fisheries Research Board of Canada 36(6): 706-707.

McAllister, Don E. 1979. Review of: Anatomie de Latimeria chalumnae. Tome III. Appareil digestif - appareil respiratoire - appareil urogénital - glandes endocrines - appareil circulatoire - teguments - écailles - conclusions générales" by J. Millot, J. Anthony and D. Robineau. Journal of the Fisheries Research Board of Canada 36(6): 707708 .

Champagne, Donald E., C. R. Harington, and Don E. McAllister. 1979. Deepwater sculpin, Myoxocephalus thompsoni (Girard) from a Pleistocene nodule, Green Creek, Ontario, Canada. Canadian Journal of Earth Sciences, 16(8): 1621-1628, 3 figures.

Gilbert, Carter R., Charles H. Hocutt, Robert E. Jenkins, Don E. McAllister, and Jay R. Stauffer, Jr. 1980. Atlas of North American Freshwater Fishes. North Carolina State Museum of Natural History, Raleigh. $x+867$ pages, numerous maps and figures.

Kenneth, Able W., and Don E. McAllister. 1981. Revision of the snailfish genus Liparis from Arctic Canada. Canadian Bulletin of Fisheries and Aquatic Sciences, 208 (1980): viii +52 pages, 27 figures, 7 tables.

McAllister, Don E. 1981. Review of: Order in Living Organisms: a systems analysis of evolution by Rupert Riedl. Canadian Field-Naturalist, 95(1): 120.

McAllister, Don E., and R. Jon Planck. 1981. Capturing fish measurements and counts with calipers and probe interfaced with a computer or pocket calculator. Canadian Journal of Fisheries and Aquatic Sciences 38(4): 466-470, 4 figures.

McAllister, Don E., and Denis St-Onge. 1981. Postglacial fossil fishes from Coppermine River, Northwest Territories, Canada. Canadian Field-Naturalist 95(2): 203-205.

Gilhen, John, and Don E. McAllister, 1981. First Nova Scotian and second Canadian record of Atlantic fanfish, Pterycombus brama Fries, 1837 (Bramidae). Proceedings of the Nova Scotian Institute of Science 30(3/4) [1980]: 191-193, 1 figure.

McAllister, Don E. 1981. Review of: Charrs: salmonid fishes of the genus Salvelinus, edited by Eugene K. Balon. Canadian Field-Naturalist, 95(2): 220-221.

McAllister, Don E., M. Eric Anderson, and J. G. Hunter. 1981. Deep-water eelpouts, Zoarcidae, from Arctic Canada and Alaska. Canadian Journal of Fisheries and Aquatic Sciences 38(7): 821-839, 5 figures.

McAllister, Don E. 1981. Review of: The Freshwater Fishes of Alaska by James E. Morrow. Canadian Field-Naturalist 95(3): 375 .

McAllister, Don E., Stephen L. Cumbaa, and C. R. Harington. 1981. Pleistocene fishes (Coregonus, Osmerus, Microgadus, Gasterosteus) from Green Creek, Ontario, Canada. Canadian Journal of Earth Sciences 18(8): 1356-1364, 3 figures. 
Cumbaa, Stephen L., Don E. McAllister and Richard E. Morlan. 1981. Late Pleistocene fish fossils of Coregonus, Stenodus, Thymallus, Catostomus, Lota, and Cottus from the Old Crow basin, northern Yukon, Canada. Canadian Journal of Earth Sciences, 18(11): 1740-1754, 8 figures.

Jean, Yves, Alex E. Peden, and Don E. McAllister. 1981. English, French and scientific names of Pacific fish of Canada/Noms français, anglais et scientifiques des poissons de la côte du Pacifique du Canada. British Columbia Provincial Museum Heritage Record 13: 1-51, 1 figure.

McAllister, Don E. 1982. Review of: Les salmonidés des eaux de la Plaine de Montréal: 1. Historique, 1534-1977 et 2. Biometrie, biogéographie, 1970-1975, et registre des pêches 1941-1976 by Vianney Legendre, Jean-René Mongeau, Jean Leclerc et Jocelyne Brisebois. Canadian FieldNaturalist 95(4): 486-487.

Gilhen, John, and Don E. McAllister. 1982. First Canadian record of yellowfin bass, Anthias nicholsi Firth, taken off Nova Scotia. Proceedings of the Nova Scotian Institute of Science 31(3/4) [1981]: 251-254, 1 figure.

McAllister, Don E. 1982. Review of: A Handbook of Fish Habitat Protection on Forest Lands in British Columbia by D. A. A. Toews and M. J. Brownlee. Canadian FieldNaturalist 96(2): 240.

McAllister, Don E., and Frederick W. Schueler. 1982. Review of Systematics and Biogeography, Cladistics and Vicariance by Gareth Nelson and Norman Platnick. Canadian Field-Naturalist 96(2): 246-247.

Godkin, C. M., W. J. Christie, and D. E. McAllister. 1982. Problems of species identity in the Lake Ontario sculpins, Cottus bairdi and C. cognatus. Canadian Journal of Fisheries and Aquatic Sciences 39(10): 1373-1382, 6 figures, 4 tables.

Shih, C. T., and Don E. McAllister. 1982. Review of: New Chinese fish books [Freshwater fishes of Guangxi/Fishes of Tumen River]. Copeia 1982(4): 979-980.

Steigerwald, Michèle Bélanger, and Don E. McAllister. 1982. List of the Canadian marine fish species in the National Museum of Natural Sciences, National Museums of Canada/Liste des espèces de poissons marins du Canada au Musée national des sciences naturelles, Musées nationaux du Canada. Syllogeus 41: 1-30, 2 figures.

Lanteigne, Jacqueline, and Don E. McAllister. 1983. The pygmy smelt, Osmerus spectrum Cope, 1870, a forgotten sibling species of eastern North American fish. Syllogeus 45:1-32, 6 figures, 3 tables.

McAllister, Don E. 1983. An introduction to minicomputers in museums. Syllogeus 44:105-136, 14 figures.

McAllister, Don E., and C. T. Shih. 1983. Review of: The Fishes of the Islands in the South China Sea by South China Sea Fisheries Institute et al. Canadian Field-Naturalist 97(1): 133-134.

McAllister, Don E., and C. T. Shih. 1983. Review of: A study of the lateral-line canals system and that of Lorenzini ampullae and tubules of elasmobranchiate fishes of China by Yuanting T. Chu and Ching Wen Meng. Canadian FieldNaturalist 97(1): 134.

\#McAllister, D. E. 1983. Biogeography of marine fishes of Arctic Canada, pages 14-16 in Proceedings of the Thirtysixth Meeting of the Canadian Conference for Fisheries Research held at Winnipeg, January 3 and 4, 1983.

Hunter, J. G., Shirley T. Leach, Don E. McAllister, and Michèle Bélanger Steigerwald. 1984. A distributional atlas of records of the marine fishes of Arctic Canada in the
National Museums of Canada and Arctic Biological Station. Syllogeus 52: 1-35, 3 text figures, 21 plates.

McAllister, D. 1984. Osmeridae, Pages 399-402, 3 figures, 3 maps in Fishes of the North-eastern Atlantic and the Mediterranean/Poissons de l'Atlantique du Nord-Est et de la Méditerranée, edited by P. J. P. Whitehead, M.-L. Bauchot, J.-C. Hureau, J. Nielsen, and E. Tortonese. UNESCO, Paris. Volume 1: 1-510.

McAllister, Don E., Brad J. Parker, and Paul M. McKee. 1985. Rare, endangered and extinct fishes in Canada. Syllogeus 54: 1-192, 60 figures.

Gilhen, John, Charles G. Gruchy, and Don E. McAllister. 1985. The cubera snapper, Lutjanus cyanopterus (Cuvier) (Pisces: Lutjanidae) new to Nova Scotia and Canada. Proceedings of the Nova Scotian Institute of Science 34(2) [1984]: 177-180, 1 figure.

Gilhen, John, and Don E. McAllister. 1985. The tripletail, Lobotes surinamensis, new to the fish fauna of the Atlantic coast of Nova Scotia and Canada. Canadian Field-Naturalist 99(1): 116-118, 1 figure.

McAllister, Don E. 1985. Review of: Vanishing Fishes of North America by R. Dana Ono, James D. Williams, and Anne Wagner. Canadian Field-Naturalist 99(2): 274-275.

McAllister, Don E. 1985. Review of: A Dictionary of Ecology, Evolution, and Systematics by R. J. Lincoln, G. A. Boxshall, and P. F. Clark. Canadian Field-Naturalist 99(2): 278-279.

McAllister, Don E. 1985. Review of: Evolution of Fish Species Flocks by Anthony A. Echelle and Irv Kornfield. Canadian Journal of Fisheries and Aquatic Sciences 42(8): 1443-1444.

McAllister, D. E. 1985. Endangered animals, page 571-572, 2 figures in The Canadian Encyclopedia, Volume I, A-For. xxxv $+1-666$ pages. Hurtig Publishers, Edmonton, Alberta [this, and the next two articles, appeared also in subsequent editions of the Canadian Encyclopedia].

McAllister, D. E. 1985. Smelt, page 1707 in The Canadian Encyclopedia, Volume III, Pat-Z. Index. Pages 1373-2089. Hurtig Publishers, Edmonton, Alberta.

McAllister, D. E. 1985. Sturgeon, page 1768, 1 figure in The Canadian Encyclopedia, Volume III, Pat-Z. Index. Hurtig Publishers, Edmonton, Alberta.

McAllister, Don E., and Brian W. Coad. 1985. Review of: Fishes of the North-Eastern Atlantic and the Mediterranean/Poissons de l'Atlantique du Nord-Est et de la Méditerranée edited by P. J. P. Whitehead, M.-L. Bauchot, J.-C. Hureau, J. Nielsen, and E. Tortonese. Canadian Journal of Fisheries and Aquatic Sciences 42(11): 1852.

McAllister, Don E. 1985. Review of: Caribbean Fish Life: Index to the local and scientific names of the marine fishes and fishlike invertebrates of the Caribbean area (tropical western central Atlantic Ocean) by Jacques S. Zaneveld. Canadian Field-Naturalist 99(3): 459-460.

McAllister, Don E. 1985. Review of: The American Darters by Robert A. Kuehne and Roger W. Barbour. Canadian Field-Naturalist 99(3): 460-461.

McAllister, Don E. 1985. Review of: Scientific Studies on Hudson and James Bays/Recherches sur la baie d'Hudson et la baie James. Volume I and II. Edited by I. P. Martini. Canadian Field-Naturalist 99(3): 464-465. 31 December 1985.

McAllister, Don E., Steven P. Platania, Frederick W. Schueler, M. Elizabeth Baldwin, and David S. Lee. 1986. Ichthyofaunal patterns on a geographic grid, pages 17-51, 9 figures, 1 table in The Zoogeography of North American 
Freshwater Fishes. Edited by Charles H. Hocutt and E. O. Wiley. John Wiley \& Sons, New York. xiii +866 pages.

Crossman, E. J., and Don E. McAllister. 1986. Zoogeography of freshwater fishes of the Hudson Bay drainage, Ungava Bay and the Arctic Archipelago, pages 53-104, 7 figures, 2 tables in The Zoogeography of North American Freshwater Fishes. Edited by Charles H. Hocutt, and E. O. Wiley. John Wiley \& Sons, New York. xiii +866 pages.

McAllister, Don E. 1986. Technique of making fish illustration 16: gyotaku, direct prints from fish specimens. Environmental Biology of Fishes 15(2): 90, 1 figure.

McAllister, Don E. 1986. Use of small nets instead of cyanide for collecting aquarium fishes in the Philippines. Program of the 66th Annual Meeting of the American Society of Ichthyologists and Herpetologists, Victoria, British Columbia June 1986. 1 page. [abstract].

McAllister, Don E. 1986. Review of: An atlas of distribution of the freshwater fish families of the world by T. M. Berra. Experimental Biology 45(1): 65-66.

McAllister, Don E. 1986. Obituary of Vadim Dimitrovitch Vladykov, 1898-1986. Environmental Biology of Fishes 15(4): 241-242, 1 photograph.

McAllister, D. E., and W. B. Scott. 1986. Vadim Dmitrivitch Vladykov 1898-1986. Transactions of the Royal Society of Canada, Series V, Volume 1: 348-351, 1 photograph.

Renaud, Claude B., Lawrence I. Speers, Sami U. Qadri, and Don E. McAllister. 1986. Biochemical evidence of speciation in the cod genus Gadus. Canadian Journal of Zoology 64(7): 1563-1566, 1 figure, 3 tables.

McAllister, Don E., and Peter J. Rubec. 1986. Aquino government approves program to end cyanide use in the Philippines for the collection of tropical marine fishes. Environmental Biology of Fishes 17(4): 315-317.

McAllister, Don E., and Brian W. Coad. 1986. Review of: Fishes of the North-Eastern Atlantic and the Mediterranean/ Poissons de l'Atlantique du Nord-Est et de la Méditerranée edited by P. J. P. Whitehead, M.-L. Bauchot, J.-C. Hureau, J. Nielsen, and E. Tortonese. Canadian Field-Naturalist 100(1): 152-153.

Prouse, N. J., and Don E. McAllister. 1986. The glacial eelpout, Lycodes frigidus, from the Arctic Canadian Basin, new to the Canadian ichthyofauna. Canadian Field-Naturalist 100(3): 325-329, 2 figures.

McAllister, Don E. 1986. Review of: The Trumpeter: voices from the Canadian ecophilosophy network edited by Alan R. Drengson. Canadian Field-Naturalist 100(3): 455.

Waller, Robert, and Don E. McAllister. 1986. A spot test for distinguishing formalin from alcohol solutions, pages. 93-99, 4 figures, 1 table. In Proceedings of the 1985 Workshop on Care and Maintenance of Natural History Collections. Edited by Janet Waddington and David M. Rudkin. Royal Ontario Museum, Life Sciences Miscellaneous Publications. $\mathrm{v}+121$ pages.

McAllister, Don E., Editor and partial author. 1987. Sea Wind, Bulletin of the International Marinelife Alliance, Ottawa 1(1): 1-32, 18 figures.

McAllister, Don E., and Jane Topping. 1987. Triton's trumpet shell - predator of coral reef destroying Crown of Thorns starfish? Sea Wind, Bulletin of the International Marinelife Alliance, Ottawa 1(1): 6-9, 2 figures.

McAllister, Don E., and Michèle Bélanger Steigerwald. 1987. Bibliography of the marine fishes of Arctic Canada 1771-1985. Canadian Manuscript Report of Fisheries and Aquatic Sciences, 1909(1986): v +108 pages, 2 figures.
McAllister, Don E., Vianney Legendre, et J. G. Hunter. 1987. Liste des noms inuktitut (esquimaux), français, anglais et scientifiques des poissons marins du Canada arctique/List of Inuktitut (Eskimo), French, English and Scientific names of marine fishes of Arctic Canada. Rapport manuscrit canadien des sciences halieutiques et aquatiques, 1932: $v+106$ pages, 1 figure.

McAllister, Don E., Editor and partial author. 1987. Sea Wind, Bulletin of the International Marinelife Alliance, Ottawa, 1(2):1-32, 19 figures.

McAllister, Don E. 1987. The co-operative gene. Sea Wind, Bulletin of the International Marinelife Alliance, Ottawa 1(2): 25-26, 2 figures.

McAllister, Don E. 1987. Review of: Sea Fishes of the World (Indo-Pacific region) by Hajime Masuda and Gerald R. Allen. Sea Wind Bulletin of the International Marinelife Alliance, Ottawa 1(2): 28-29.

\#McAllister, Don E. 1987. A computerized working world fish list. American Society of Ichthyologists and Herpetologists, Albany, New York, June 1987, page 66 [abstract].

Waller, Robert, and Don E. McAllister. 1987. A spot test to distinguish formalin from alcohol solutions. Curator 30(3): 240-249, 3 figures, 1 table.

McAllister, Don E., Editor and partial author. 1987. Sea Wind, Bulletin of the International Marinelife Alliance, Ottawa 1(3): 1-32, 21 figures.

McAllister, Don E. 1987. How many fish species in the sea? Sea Wind, Bulletin of the International Marinelife Alliance, Ottawa 1(3): 17-18, 1 figure.

McAllister, Don E. 1987. Collecting aquarium fish with other chemicals than cyanide? Sea Wind, Bulletin of the International Marinelife Alliance, Ottawa 1(3): 19-20, 1 figure.

McAllister, Don E. 1987. Review of: Our Common Future by Gro Harlem Brundtland. Sea Wind, Bulletin of the International Marinelife Alliance, Ottawa 1(3): 22-24.

McAllister, Don E. 1987. Mine pollution at Marinduque Island in the Philippines. Sea Wind, Bulletin of the International Marinelife Alliance, Ottawa 1(3): 26-27, 2 figures.

McAllister, Don E. 1987. The co-operative gene. Corals. Sea Wind, Bulletin of the International Marinelife Alliance, Ottawa 1(3): 28-29, 3 figures.

McAllister, D. E. 1987. Status of the central stoneroller, Campostoma anomalum, in Canada. Canadian Field-Naturalist 101(2): 213-218, 2 figures.

McAllister, D. E. 1987. Status of the blackstripe topminnow, Fundulus notatus, in Canada. Canadian Field-Naturalist 101(2): 219-225, 3 figures.

McAllister, Don E., Editor and partial author. 1987. Sea Wind, Bulletin of the International Marinelife Alliance, Ottawa 1(4): 1-35, 20 figures.

McAllister, Don E. 1987. A test for cyanide-caught fish. Sea Wind, Bulletin of the International Marinelife Alliance, Ottawa 1(4): 6-9, 2 figures.

McAllister, Don E. 1987. The biggest great white shark. Sea Wind, Bulletin of the International Marinelife Alliance, Ottawa 1(4): 11-14, 1 figure.

McAllister, Don E. 1987. Review of Haiku edited by Dorothy Howard and Andre. Sea Wind, Bulletin of the International Marinelife Alliance, Ottawa 1(4): 30-31.

\#McAllister, D. E. 1987. Priorities for ichthyological research in the Canadian Arctic Archipelago. Program and Abstracts, The Canadian Arctic Islands, Canada's Missing Dimension, An International Meeting sponsored by the National Museum of Natural Sciences, Ottawa, Canada, November 21-24, 1987, page 77 [abstract]. 
McAllister, Don E., Editor and partial author. 1988. Sea Wind, Bulletin of the International Marinelife Alliance, Ottawa 2(1): 1-36, 15 figures.

McAllister, Don E. 1988. Review of: NAGA, The ICLARM Quartery (sic) edited by Jay L. Maclean. Sea Wind, Bulletin of the International Marinelife Alliance, Ottawa 2(1): 1718.

McAllister, Don E. 1988. Shiraho coral reef report submitted. Sea Wind, Bulletin of the International Marinelife Alliance, Ottawa 2(1): 20-23, 2 figures.

McAllister, Don E. 1988. Review of: Sea fishes of southern Australia by Barry Hutchins and Roger Swainston. Sea Wind, Bulletin of the International Marinelife Alliance, Ottawa 2(1): 30-31.

McAllister, Don E. 1988. Review of: Endangered species, Canada's disappearing wildlife by Clive Roots. Sea Wind, Bulletin of the International Marinelife Alliance, Ottawa 2(1): 31

Planck, R. Jon, Don E. McAllister, and Angus T. McAllister. 1988. Shiraho Coral Reef \& the proposed new Ishigaki Island Airport, Japan with a review of the coral reefs of the Ryukyu Archipelago, Japan. International Marinelife Alliance, Ottawa 220 pages, 21 figures.

McAllister, Don E. 1988. A glowing future for marine aquarium fishes... the peaceful Philippine revolution under the seas. Tropical Fish Hobbyist 36(12): 84-86, 3 colour photographs.

McAllister, Don E. 1988. Vadim Dimitrievitch Vladykov: life of an ichthyologist. Environmental Biology of Fishes 23(1/2): 9-20, 9 figures.

Coad, Brian W., Don E. McAllister, and Claude B. Renaud. 1988. Bibliography of Vadim D. Vladykov: scientific publications and manuscript reports 1923-1988. Environmental Biology of Fishes 23(1/2): 21-36.

Renaud, Claude B., and Don E. McAllister. 1988. Taxonomic status of the extinct Banff longnose dace, Rhinichthys cataractae smithi, of Banff National Park, Alberta. Environmental Biology of Fishes 23(1/2): 95-113, 4 figures, 1 table.

McAllister, Don E., and Edward Kott. Guest Editors. 1988. On lampreys and fishes: a memorial anthology in honor of Vadim D. Vladykov. Developments in Environmental Biology of Fishes, 8: 1-162 pages, 69 figures, 20 tables [reprinted from Environmental Biology of Fishes 23(1/2)].

McAllister, Don E., Editor and partial author. 1988. Sea Wind, Bulletin of the International Marinelife Alliance, Ottawa 2(2): 1-36, 21 figures.

McAllister, Don E. 1988. Review of: The Crown of Thorns Starfish edited by Leon Zann and Elaine Eager. Sea Wind, Bulletin of the International Marinelife Alliance, Ottawa 2(2): 29-30.

McAllister, Don E. 1988. Review of: Ellisella the coral by Katherine Muzik and Makota Wada. Sea Wind, Bulletin of the International Marinelife Alliance, Ottawa 2(2): 3132.

Coad, Brian W., Don E. McAllister, and D. Max Blouw. 1988. Morphological diagnosis of the white stickleback of Canada. Program and Abstracts, 75th Annual Meeting of the American Society of Ichthyologists and Herpetologists, University of Michigan, Ann Arbor, June 24-29, 1988, page 76 [abstract].

McAllister, D. E. 1988. Verzamelen van aquariumvissen met andere middelen dan cyanide? Het Zee-Aquarium 38(6): 126-127.
McAllister, Don E. 1988. Review of: Biology of the Arctic Charr: Proceedings of the International Symposium on Arctic Charr edited by Lionel Johnson and Bonnie Burns. Canadian Field-Naturalist 101(4)[1987]: 642-643.

McAllister, Don E. 1988. Review of: Fishes of the Northeastern Atlantic and the Mediterranean/Poissons de l'Atlantique du Nord-Est et de la Méditerranée $b y$ P. J. P. Whitehead, M.-L. Bauchot, J.-C. Hureau, J. Nielsen, and E. Tortonese. Canadian Field-Naturalist 101(4) [1987]: 646.

McAllister, Don E. 1988. Review of: The Inland Fishes of New York State by C. Lavett Smith. Canadian Field-Naturalist 101(4)[1987]: 646-647. 19 July 1988

McAllister, Don E. 1988. Review of: Biology of the Arctic charr: Proceedings of the International Symposium on Arctic Charr edited by L. Johnson, B. Burns. Experimental Biology 47(3): 182.

McAllister, Don E., Editor and partial author. 1988. Sea Wind, Bulletin of the International Marinelife Alliance, Ottawa 2(3): 1-36, 20 figures.

McAllister, Don E. 1988. The high price of periodicals \& Third World countries. What price knowledge? Sea Wind, Bulletin of the International Marinelife Alliance, Ottawa 2(3): 22-24.

McAllister, Don E. 1988. Review of: Coastal fishes of the Pacific northwest by Andy Lamb and Phil Edgell. Sea Wind, Bulletin of the International Marinelife Alliance, Ottawa 2(3): 28.

McAllister, Don E. 1988. Review of: Smith's Sea Fishes by Margaret M. Smith and P. C. Heemstra. Sea Wind, Bulletin of the International Marinelife Alliance, Ottawa 2(3): 2930 .

McAllister, Don E. 1988. Review of: Towards a second green revolution, from chemical to new biological technologies in agriculture in the tropics edited by G. B. Marini-Bettolo. Sea Wind, Bulletin of the International Marinelife Alliance, Ottawa 2(3): 30.

McAllister, Don E. 1988. Review of: The natural way of farming by Masanobu Fukuoka. Sea Wind, Bulletin of the International Marinelife Alliance, Ottawa 2(3): 30.

McAllister, Don E. 1988. Review of: Proceedings of the Symposium on Subtropical-Tropical Seagrasses of the Southeastern United States edited by M. J. Durako, R. C. Phillips, and Roy R. Lewis, III. Sea Wind, Bulletin of the International Marinelife Alliance, Ottawa 2(3): 31.

McAllister, Don E. 1988. Review of: Smith's sea fishes by M. M. Smith and P. C. Heemstra. Experimental Biology 47: 226

McAllister, Don E. 1988. Environmental, economic and social costs of coral reef destruction in the Philippines. Regional Research Workshop and International Symposium on the Conservation and Management of Coral Reefs and Mangrove Ecosystems. Regional MAB/COMAR IV Meeting and First University of the Ryukyus International Symposium, 24 September-4 October, 1987. 38 pages, 7 figures.

McAllister, Don E. 1988. About the Philippines. Pet Business, Orlando 14(11): 29.

McAllister, Don E., Editor and partial author. 1988. Sea Wind, Bulletin of the International Marinelife Alliance, Ottawa 2(4): 1-36, 17 figures.

McAllister, Don E. 1988. Old fourlegs, the coelacanth. Sea Wind, Bulletin of the International Marinelife Alliance, Ottawa 2(4): 6-9, 1 figure. 
McAllister, Don E. 1988. Acid rain and the sea. Sea Wind, Bulletin of the International Marinelife Alliance, Ottawa 2(4): 13-15.

McAllister, Don E. 1988. Unsung national hero discovered. Sea Wind, Bulletin of the International Marinelife Alliance, Ottawa 2(4): 26.

McAllister, Don E. 1988. What one person can do! Sea Wind, Bulletin of the International Marinelife Alliance, Ottawa 2(4): 28

McAllister, Don E. 1988. Review of: Guide illustré de la faune aquatique dans l'art grec by Jean Delorme and Charles Roux. Sea Wind, Bulletin of the International Marinelife Alliance, Ottawa 2(4): 29-31.

McAllister, Don E. 1988. Review of: ICOD info. The Newsletter of the International Centre for Ocean Development. Sea Wind, Bulletin of the International Marinelife Alliance, Ottawa 2(4): 32-33.

McAllister, Don E. 1988. Review of: The freshwater fishes of Europe, Volume 1, part 1. Petromyzontiformes edited by J. Holcik. Experimental Biology 48(1): 50.

McAllister, Don E., Editor and partial author. 1989. Sea Wind, Bulletin of the International Marinelife Alliance, Ottawa 3(1): 1-36, 14 figures.

McAllister, Don E. 1989. Aquaculture, yes, no, maybe? Sea Wind, Bulletin of the International Marinelife Alliance, Ottawa 3(1): 13-18.

McAllister, Don E. 1989. Listen to the wind. Sea Wind, Bulletin of the International Marinelife Alliance, Ottawa 3(1): 24.

McAllister, Don E. 1989. What one person can do. Sea Wind, Bulletin of the International Marinelife Alliance, Ottawa 3(1): 25 .

McAllister, Don E. 1989. An alternative to Canada's proposed nuclear submarine fleet. Sea Wind, Bulletin of the International Marinelife Alliance, Ottawa 3(1): 26-28.

McAllister, Don E. 1989. Formation of IUCN Coral Fish Protection Committee announced. Marine Fish Monthly 3(12): 42

McAllister, Don E., C. R. Harington, S. L. Cumbaa, and Claude B. Renaud. 1989. Paleoenvironmental and biogeographic analyses of fossil fishes in peri-Champlain Sea deposits in eastern Canada, pages 241-258, 12 figures, 1 table in The Late Quaternary Development of the Champlain Sea Basin. Edited by N. R. Gadd. Geological Association of Canada, Special Paper 35.

McAllister, Don. 1989. Threats to coral fishes. Species, Newsletter of the Species Survival Commission 12: 3334, 2 figures.

McAllister, Don E., Editor and partial author. 1989. Sea Wind, Bulletin of the International Marinelife Alliance, Ottawa 3(2): 1-36, 10 figures.

McAllister, Don E. 1989. One globe, links between freshwater, sea and air. Thinking eco-system-atic-ally. Sea Wind, Bulletin of the International Marinelife Alliance, Ottawa 3(2): 5-6, 1 figure.

McAllister, Don E. 1989. What can one person do? Sea Wind, Bulletin of the International Marinelife Alliance, Ottawa 3(2): 16

McAllister, Don E. 1989. Review of: Coral Reefs of Florida by Gilbert L. Voss. Sea Wind, Bulletin of the International Marinelife Alliance, Ottawa 3(2): 30-31.

McAllister, Don E. 1989. Review of: Ocean Realm. Sea Wind, Bulletin of the International Marinelife Alliance, Ottawa 3(2): 31 .
McAllister, Don E. 1989. Review of: Peces nicaragüenses by Jaime Villa. Sea Wind, Bulletin of the International Marinelife Alliance, Ottawa 3(2): 33-34.

McAllister, Don E. 1989. Review of: World symposium on fishing gear and fishing vessel design. Sea Wind, Bulletin of the International Marinelife Alliance, Ottawa 3(2): 3435 .

McAllister, Don E. 1989. Review of: Corals and coral reefs in the Caribbean. A manual for students by Stafford A. Griffith and Eugenie William. Sea Wind, Bulletin of the International Marinelife Alliance, Ottawa 3(2): 35

McAllister, Don E., Editor and partial author. 1989. Sea Wind, Bulletin of the International Marinelife Alliance, Ottawa 3(3): 1-36, 11 figures.

McAllister, Don E. 1989. Seahorses. Sea Wind, Bulletin of the International Marinelife Alliance, Ottawa 3(3): 6, 1 figure.

McAllister, Don E. 1989. Ship's ballast water and introduction of exotic fauna and flora: biological pollution. Sea Wind, Bulletin of the International Marinelife Alliance, Ottawa 3(3): 16-17, 1 figure.

McAllister, Don E. 1989. What can I do? Sea Wind, Bulletin of the International Marinelife Alliance, Ottawa 3(3): 18.

McAllister, Don E. 1989. Ozone layer depletion and sealife Sea Wind, Bulletin of the International Marinelife Alliance, Ottawa 3(3): 24-27, 1 figure.

McAllister, Don E. 1989. Review of: Coral reef fishes of Aruba, Bonaire and Curaçao by Dr. Wil Nagelkerken. Sea Wind, Bulletin of the International Marinelife Alliance, Ottawa 3(3): 27-28.

McAllister, Don E. 1989. Review of: Sharks of Polynesia by R. H. Johnson. Sea Wind, Bulletin of the International Marinelife Alliance, Ottawa 3(3): 28-29.

McAllister, Don E. 1989. Review of: California Waterfront Age edited by Rasa Gustatis. Sea Wind, Bulletin of the International Marinelife Alliance, Ottawa 3(3): 29-30.

McAllister, Don E. 1989. Review of: Underwater farming by George S. Fichter. Sea Wind, Bulletin of the International Marinelife Alliance, Ottawa 3(3): 30-31.

McAllister, Don E. 1989. Review of Marine Turtle Newsletter edited by Nat B. Frazer. Sea Wind, Bulletin of the International Marinelife Alliance, Ottawa 3(3): 34.

McAllister, Don E. 1989. Environmental, economic and social costs of coral reef destruction in the Philippines. Galaxea 7(1988): 161-178, 7 figures.

McAllister, Don E., Editor and partial author. 1989. Sea Wind, Bulletin of the International Marinelife Alliance, Ottawa 3(4): 1-36, 12 figures.

McAllister, Don E. 1989. Coral reef rugosity and health, a quick automated field measure. Sea Wind, Bulletin of the International Marinelife Alliance, Ottawa 3(4): 25-29, 2 figures.

McAllister, Don E. 1989. What one person can do. Sea Wind, Bulletin of the International Marinelife Alliance, Ottawa 3(4): 31-32.

McAllister, Don E. 1989. Review of: Peces de las aguas continentales de Costa Rica by William A. Bussing. Sea Wind, Bulletin of the International Marinelife Alliance, Ottawa 3(4): 33

McAllister, Don E. 1989. Review of: The IDRC Reports $b y$ International Development Research Centre, Ottawa. Sea Wind, Bulletin of the International Marinelife Alliance, Ottawa 3(4): 33-34.

McAllister, Don E. 1989. Review of: NAGA. The ICLARM Quarterly. Sea Wind, Bulletin of the International Marinelife Alliance, Ottawa, 3(4): 34. 
McAllister, Don E. 1989. Review of: Environmental impact assessment and environmental policy in Japan" by Brendan F. D. Barrett. Sea Wind, Bulletin of the International Marinelife Alliance, Ottawa 3(4): 35.

McAllister, Don E. 1989. Coral reefs and oceans. Paper presented at the "Our Commonworld" Conference, Toronto, 1989. MS, 6 pages.

\#McAllister, D. E. 1989. Fishes and benthic invertebrates of Hudson Strait. Atelier sur le Detroit d'Hudson Strait Workshop, Novembre 9-10 November 1989, Holiday Inn Pointe-Claire. Supplementary pages, 36A-36D [abstract].

Williams, Jack E., James E. Johnson, Dean A. Hendrickson, Salvador Contreras-Balderas, James D. Williams, Miguel Navarro-Mendoza, Don E. McAllister, and James E. Decon. 1990. Fishes of North America endangered, threatened, or of special concern: 1989. Fisheries 14(6) [1989]: 2-20, 4 colour plates, 2 tables, 1 appendix.

McAllister, Don E., Editor and partial author. 1990. Sea Wind, Bulletin of the International Marinelife Alliance, Ottawa 4(1): 1-40, 15 figures.

McAllister, Don E. 1990. Review of: The conservation of nature by the Nature Conservancy of Japan. Sea Wind, Bulletin of the International Marinelife Alliance, Ottawa 4(1): 33-34.

McAllister, Don E. 1990. Review of: A citizen's guide to plastics in the ocean: more than a litter problem by Kathryn J. O'Hara. Sea Wind, Bulletin of the International Marinelife Alliance, Ottawa 4(1): 35.

McAllister, Don E. 1990. Review of: Reservoir fishery management and development in Asia Edited by Seno S. De Sylva. Sea Wind, Bulletin of the International Marinelife Alliance, Ottawa 4(1): 37-38.

McAllister, Don E., Editor and partial author. 1990. Sea Wind, Bulletin of the International Marinelife Alliance, Ottawa 4(2): 1-36, 19 figures.

McAllister, Don E. 1990. Review of: Directory of Environmental NGO's in the Asia-Pacific Region by Sahabat Alam Malaysia. Sea Wind, Bulletin of the International Marinelife Alliance, Ottawa 4(2): 33.

McAllister, Don E. 1990. Review of: Poisoners of the seas by K. A. Gourlay. Sea Wind, Bulletin of the International Marinelife Alliance, Ottawa 4(2): 34.

\#McAllister, Don E. 1990. A national aquarium for the Philippines. Let's Conserve Our Natural Resources. Part 36. Greenfields, Makati, Manila 20(1): 8-10.

McAllister, Don E., Editor and partial author. 1990. Sea Wind, Bulletin of the International Marinelife Alliance, Ottawa 4(3): 1-36, 16 figures.

McAllister, Don E. 1990. Bannerfishes, genus Heniochus. Sea Wind, Bulletin of the International Marinelife Alliance, Ottawa 4(3): 8-9, 2 figures.

McAllister, Don E. 1990. Review of: The freshwater fishes of Western Borneo (Kalimantan Barat, Indonesia) by Tyson R. Roberts. Sea Wind, Bulletin of the International Marinelife Alliance, Ottawa 4(3): 32-33.

McAllister, Don E. 1990. Review of: Ecos. January 1990 issue of a new ecology magazine. Sea Wind, Bulletin of the International Marinelife Alliance, Ottawa 4(3): 34-35.

McAllister, Don E. 1990. Review of: Atlantic Fishes of Canada by W. B. Scott and M. G. Scott. Canadian FieldNaturalist 103(4): 618-619. 26 September.

McAllister, Don E., Editor and partial author. 1990. Sea Wind, Bulletin of the International Marinelife Alliance, Ottawa 4(4): 1-36, 17 figures.
McAllister, Don E. 1990. Monoculture vs polyculture. Sea Wind, Bulletin of the International Marinelife Alliance, Ottawa 4(4): 8-9.

McAllister, Don E. 1990. Power of the pen. Sea Wind, Bulletin of the International Marinelife Alliance, Ottawa 4(4): 24-25.

McAllister, Don E. 1990. The ocean as a dump. Sea Wind, Bulletin of the International Marinelife Alliance, Ottawa, 4(4): 27-28.

McAllister, Don E. 1990. What one person can do. Sea Wind, Bulletin of the International Marinelife Alliance, Ottawa 4(4): 29.

McAllister, Don E. 1990. Review of: COT Newsletter. Sea Wind, Bulletin of the International Marinelife Alliance, Ottawa 4(4): 34.

McAllister, Don E. 1990. Review of: Canopy International. Sea Wind, Bulletin of the International Marinelife Alliance, Ottawa 4(4): 34-35.

McAllister, Don E. 1990. Priorities for ichthyological research in the Canadian Arctic Archipelago, pages 512-515, 5 figures, in Canada's Missing Dimension. Science and History in the Canadian Arctic Islands. Volume II. Edited by C. R. Harrington Canadian Museum of Nature, Ottawa. Pages 444-855.

McAllister, D. E. 1990. Diversity and biology of invertebrates and fish, pages 120-126 in Compte Rendu d'un Atelier: Études de l'écosytème marin du détroit d'Hudson/ Proceedings of workshop: Marine ecosystem studies in Hudson Strait, Novembre 9-10 November, 1989, Montréal, Québec. Edited by J. A. Percy. Canadian Technical Report of Fisheries and Aquatic Sciences 1770: xiv +175 pages.

McAllister, Don E. 1990. A List of the Fishes of Canada/ Liste des poissons du Canada. Syllogeus 64: 1-310, 32 figures.

Houston, J., and D. E. McAllister. 1990. Status of the Bering wolffish, Anarhichas orientalis, in Canada. Canadian FieldNaturalist 104(1): 20-23, 3 figures.

Houston, J., and D. E. McAllister. 1990. Status of the blackline prickleback, Acantholumpenus mackayi, in Canada. Canadian Field-Naturalist 104(1): 24-28, 3 figures.

McAllister, Don E., Editor and partial author. 1991. Sea Wind, Bulletin of Ocean Voice and International Marinelife Alliance, Ottawa 5(1): 1-36, 18 figures.

McAllister, Don E. 1991. A glimpse of wild sea otters! Sea Wind, Bulletin of Ocean Voice and International Marinelife Alliance, Ottawa 5(1): 8-9, 1 figure.

McAllister, Don E. 1991. What is the status of the world's coral reef fishes? Sea Wind, Bulletin of Ocean Voice and International Marinelife Alliance, Ottawa 5(1): 14-18, 2 figures.

McAllister, Don E. 1991. What is a coral reef worth? Sea Wind, Bulletin of Ocean Voice and International Marinelife Alliance, Ottawa, 5(1): 21-24.

Howlett, David H., and Don E. McAllister. 1991. PADI's scuba diver environmental A.W.A.R.E. Program. Sea Wind, Bulletin of Ocean Voice and International Marinelife Alliance, Ottawa 5(1): 24-25.

McAllister, Don E., Editor and partial author/Editeur et auteur en partie. 1991. Canadian Biodiversity, Ottawa 1(1): 1-48, numerous text figures; Bulletin canadien de la biodiversité, Ottawa 1(1): 1-52, plusieurs schémas dans le texte.

McAllister, Don E. 1991. What is biodiversity? Canadian Biodiversity, Ottawa 1(1): 4-6, 1 figure; Qu'est-ce que la biodiversité? Bulletin canadien de la biodiversité, Ottawa 1(1): 4-6, 1 figure. 
McAllister, Don E. 1991. Why save biodiversity? Rationales and ethics. Canadian Biodiversity, Ottawa 1(1): 8-13, 2 figures; Vers la rationalisation de la conservation de la biodiversité. Bulletin canadien de la biodiversité, Ottawa 1(1): 8-14, 2 figures.

Schueler, Frederick W., and Don E. McAllister. 1991. Maps of the number of tree species in Canada: A pilot GIS study of tree biodiversity. Part 1. Canadian Biodiversity, Ottawa 1(1): 22-29, 4 figures. Cartes de nombre d'espèces d'arbres au Canada. Une étude SIG pilote de la biodiversité des arbres: partie 1. Bulletin canadien de la biodiversité, Ottawa 1(1): 23-30, 4 figures.

McAllister, Don E. 1991. Review of: Biodiversity Network News by The Nature Conservancy, Arlington. Canadian Biodiversity, Ottawa, 1(1): 44. Bulletin canadien de la biodiversité, Ottawa 1(1): 46-47.

\#McAllister, Don E. 1991. Terumbu Karang Kita (Save our Coral Reefs). Ocean Voice International, Inc., Ottawa, World Wildlife Fund (Irian Jaya) and Indonesian Forestry Department, Irian Jaya, Indonesia. 78 pages, 58 figures.

McAllister, Don E., and Callum Roberts. 1991. GIS grids, butterflyfish (Chaetodontidae) and coral reef habit at biodiversity. Research Results Conference des Resultats de Recherche, Canadian Museum of Nature, Ottawa. March 1991 Mars, page 54 [abstract].

McAllister, Don E., Editor and partial author. 1991. Sea Wind, Bulletin of Ocean Voice International, Ottawa 5(2): 1-36, 13 figures.

McAllister, Don E. 1991. Questions about the impact of trawling. Sea Wind, Bulletin of Ocean Voice International, Ottawa 5(2): 28-32, 1 figure.

McAllister, Don E. 1991. Review of Green Teacher by Green Teacher, Toronto. Sea Wind, Bulletin of Ocean Voice International, Ottawa 5(2): 35.

McAllister, Don E., Editor and partial author/Editeur et auteur en partie. 1991. Canadian Biodiversity, Ottawa 1(2): $1-44$, numerous text figures; Bulletin canadien de la biodiversité, Ottawa 1(2): 1-48, schémas dans le texte plusieurs.

McAllister, Don E., and Erich Haber. 1991. Western yew - precious medicine. Canadian Biodiversity, Ottawa 1(2): 2-4, 2 figures.; L'if de l'Ouest, source d'un médicament précieux. Bulletin canadien de la biodiversité, Ottawa 1(2): 2-4, 2 figures.

Haber, Erich, and Don E. McAllister. 1991. The Canadian Biodiversity Data Bank. Canadian Biodiversity, Ottawa 1(2): 16-19, 3 figures. La banque canadienne de donneés sur la biodiversité. Bulletin canadien de la biodiversité, Ottawa, 1(2): 16-19, 3 figures.

McAllister, Don E. 1991. Review of: Green Teacher by Green Teacher, Toronto. Canadian Biodiversity, Ottawa 1(2): 3839; Bulletin canadien de la biodiversité, Ottawa 1(2): 41.

\#Mosquin, Theodore, and Don E. McAllister. 1991. Canadian biodiversity: A census and an appraisal. Report for the Canadian Centre for Biodiversity, Canadian Museum of Nature, Ottawa. $77+18$ pages, tables.

McAllister, Don E., Editor and partial author. 1991. Sea Wind, Bulletin of Ocean Voice International, Ottawa 5(3): 1-36, 12 figures.

McAllister, Don E. 1991. The First owes the Third World a trillion dollars. Sea Wind, Bulletin of Ocean Voice International, Ottawa, 5(3): 14-20.

McAllister, Don E. 1991. Questions on ocean impacts of James and Hudson Bay hydro projects. Sea Wind, Bulletin of Ocean Voice International, Ottawa 5(3): 22-30, 2 figures.
McAllister, Don E. 1991. Review of: The Green List/La Liste Verte. A guide to Canadian environmental organizations and agencies by the Canadian Environmental Network. Sea Wind, Bulletin of Ocean Voice International, Ottawa 5(3): 32-33.

McAllister, Don E., Editor and partial author/Editeur et auteur en partie. 1991. Canadian Biodiversity, Ottawa 1(3): 1-52, numerous text figures; Bulletin canadien de la biodiversité, Ottawa 1(3): 1-56, schémas dans le texte plusieurs.

McAllister, Don E. 1991. Estimating the pharmaceutical values of forests, Canadian and tropical. Canadian Biodiversity, Ottawa 1(3): 16-25. Une estimation de la valeur pharmaceutique des forêts canadiennes et tropicales. Bulletin canadien de la biodiversité, Ottawa 1(3): 17-27.

McAllister, Don E. 1991. Review of: The Green List/La Liste Verte. A guide to Canadian environmental organizations and agencies by the Canadian Environmental Network, Ottawa. Canadian Biodiversity, Ottawa 1(3): 47. Revue de "La Liste verte/The Green List. Le répertoire environnemental du Canada. Réseau canadien de l'environnement, Ottawa. Bulletin canadien de la biodiversité, Ottawa 1(3): 50-51.

McAllister, Don E. 1991. Review of: Tumivut. The cultural magazine of the Nunavik Inuit by the Avataq Cultural Institute, Inukjuak. Canadian Biodiversity, Ottawa 1(3): 49-50; Revue de: Tumivut. La revue culturelle des Inuit du Nunavik par Institut culturel Avataq, Inukjuak. Bulletin canadien de la biodiversité, Ottawa 1(3): 53-54.

McAllister, Don E. 1991. The secret activities of the Canadian Museum of Nature. Sea Pen (Vancouver Public Aquarium) 35(3): 13-14.

McAllister, Don E. 1991. How green is your school? Ocean Voice International, Ottawa. 16 pages, illustrated (reprinted 1993).

Edge, Thomas A., Don E. McAllister, and Sami U. Qadri. 1991. Meristic and morphometric variation between the endangered Acadian whitefish, Coregonus huntsmani, and the lake whitefish, Coregonus clupeaformis, in the Canadian Maritime Provinces and the State of Maine, USA. Canadian Journal of Fisheries and Aquatic Sciences 48(11): 2140-2151, 8 figures, 3 tables.

McAllister, Don E., Editor and partial author. 1991. Sea Wind, Bulletin of Ocean Voice International, Ottawa 5(4): 1-36, 15 figures.

McAllister, Don E. 1991. Measuring Arctic Ocean icepack shrinkage and warming: The planetary solar mirror and global thermostat. Sea Wind, Bulletin of Ocean Voice International, Ottawa 5(4): 19-24, 1 figure.

McAllister, Don E. 1991. Fish printing: Environmentally friendly work for women in coastal communities. Sea Wind, Bulletin of Ocean Voice International, Ottawa 5(4): 24-26, 1 figure.

McAllister, Don E. 1991. Review of: Women in Natural Resources. Sea Wind, Bulletin of Ocean Voice International, Ottawa 5(4): 31-32.

McAllister, Don E., Charles Anderson, and Noel Alfonso. 1992. Guide to Selected Fishes of the Maldives. International Centre for Ocean Development, Halifax. 92 pages, numerous text figures.

McAllister, Don E., Editor and partial author/Editeur et auteur en partie. 1992. Canadian Biodiversity, Ottawa 1(4): 1-52, numerous text figures; Bulletin canadien de la biodiversité, Ottawa 1(4): 1-56, schémas dans le texte plusieurs.

McAllister, Don E., and Peter G. Whiting. 1992. Biodiversity gold - a gift of First Nation North Americans to the 
planet. Canadian Biodiversity, Ottawa 1(4): 33-35. L'or de la biodiversité: un cadeau des premiers habitants de l'Amérique du Nord à la Terre. Bulletin canadien de la biodiversité, Ottawa 1(4): 39-41.

McAllister, Don E. 1992. Review of: Earthkeeper, Canada's environmental magazine. Canadian Biodiversity, Ottawa 1(4): 49; Bulletin canadien de la biodiversité, Ottawa 1(4): 54-55.

McAllister, Don E., Editor and partial author. 1992. Sea Wind, Bulletin of Ocean Voice International, Ottawa 6(1): 1-40, 12 figures.

McAllister, Don E. 1992. Review of: Aquatic Survival. Bulletin of the Aquatic Conservation Network. Sea Wind, Bulletin of Ocean Voice International, Ottawa 6(1): 1314.

McAllister, Don E., Editor and partial author/Editeur et auteur en partie. 1992. Canadian Biodiversity, Ottawa 2(1): $1-52$, numerous text figures. Bulletin canadien de la biodiversité, Ottawa, 2(1): 1-52, schémas dans le texte plusieurs.

McAllister, Don E. 1992. Review of: Fight for the forest. Chico Mendes, in his own words. Canadian Biodiversity. Ottawa 2(1): 43-44; Revue de Fight for the forest. Chico Mendes en ses propres mots. Bulletin canadien de la biodiversité, Ottawa 2(1): 43-44.

McAllister, Don E. 1992. Review of: Canadian sources of environmental information/Sources canadiennes d'information sur l'environnement. Canadian Biodiversity, Ottawa 2(1): 43-44 ; Bulletin canadien de la biodiversité, Ottawa 2(1): 44 .

McAllister, Don. 1992. The fading of Florida's coral splendor. The Ottawa Citizen, 7 March 1992.

McAllister, Don E., Editor and partial author. 1992. Sea Wind, Bulletin of Ocean Voice International, Ottawa 6(2): 1-40, 25 figures.

Ansula, Alejandro C., and Don E. McAllister. 1992. Fishing with explosives in the Philippines. Sea Wind, Bulletin of Ocean Voice International, Ottawa 6(2): 6-12, 3 figures.

McAllister, Don E. 1992. Investing in the Earth Summit Creative options for paying. Sea Wind, Bulletin of Ocean Voice International, Ottawa 6(2): 23-27, 1 figure.

McAllister, Don E. 1992. Marine biodiversity: Sea urchins. Sea Wind, Bulletin of Ocean Voice International, Ottawa 6(2): 32-33, 1 figure.

McAllister, Don E. 1992. Review of: Coral reefs edited by Z. Dubinsky. Sea Wind, Bulletin of Ocean Voice International, Ottawa,6(2): 34-36.

McAllister, Don E. 1992. Review of: World fishes, important to North Americans. Exclusive of species from continental waters of United States and Canada by C. Richard Robins (Chairperson). Sea Wind, Bulletin of Ocean Voice International, Ottawa 6(2): 37-38.

McAllister, Don E. 1992. Review of: At home in the coral reef by Katy Muzik. Sea Wind, Bulletin of Ocean Voice International, Ottawa, 6(2): 38-39.

McAllister, Don E., Editor and partial author/Editeur et auteur en partie. 1992. Canadian Biodiversity, Ottawa 2(2): $1-44$, numerous text figures; Bulletin canadien de la biodiversité, Ottawa 2(2): 1-52, schémas dans le texte plusieurs.

McAllister, Don E., and Kenneth Dalton, 1992. How global warming affects species survival. Canadian Biodiversity, Ottawa 2(2): 7-14, 1 figure : Le réchauffement du globe et la survie des espèces. Bulletin canadien de la biodiversité, Ottawa 2(2): 8-15, 1 figure.

McAllister, Don E. 1992. Antifreezes for crops and engines? Canadian Biodiversity, Ottawa 2(2):26-27, 1 figure. De l'antigel pour les récoltes et les moteurs. Bulletin canadien de la biodiversité, Ottawa 2(2): 25-26, 1 figure.

McAllister, Don. 1992. A glimpse of Earth's richness. Earthkeeper 2(6): 28-33, 4 figures.

McAllister, Don E. 1992. Review of: Profile of higher education in Canada/Profile de l'enseignement supérieur au Canada by Department of the Secretary of State, Ottawa.

McAllister, Don E., Editor and partial author. 1992. Sea Wind, Bulletin of Ocean Voice International, Ottawa 6(3): 1-40, 7 figures, 5 tables.

McAllister, Don E. 1992. What can I do? Clean beaches, clean world, and pen power. Sea Wind, Bulletin of Ocean Voice International, Ottawa 6(3): 22-25, 1 figure.

McAllister, Don E. 1992. Review of: 1992 Directory of Women in Environment by WorldWIDE Network Inc., Washington. Sea Wind, Bulletin of Ocean Voice International, Ottawa 6(3): 35.

McAllister, Don E., Editor and partial author/Editeur et auteur en partie. 1992. Canadian Biodiversity, Ottawa 2(3): $1-56$, numerous text figures. Bulletin canadien de la biodiversité, Ottawa 2(3): 1-60, schémas dans le texte plusieurs.

McAllister, Don E. 1992. Review of: The state of Canada's environment by Environment Canada, Ottawa. Canadian Biodiversity, Ottawa, 2(3): 43-45; Revue de L'État de l'environnement au Canada par Environnement Canada, Ottawa. Bulletin canadien de la biodiversité, Ottawa 2(3): 47-49.

McAllister, Don E. 1992. Review of: 1992 Directory of Women in Environment by WorldWIDE Network, Inc., Washington. Canadian Biodiversity, Ottawa 2(3): 52; Bulletin canadien de la biodiversité, Ottawa 2(3): 59.

McAllister, Don E. 1992. GIS, gyo-taku and nets in the conservation of corals, clams and coral fishes, pages 517-520. 1992 AAZPA (American Association of Zoological Parks and Aquariums) Annual Conference, Toronto, Canada, September 13-17, 1992.

McAllister, Don E., Editor and partial author. 1992. Sea Wind, Bulletin of Ocean Voice International, Ottawa 6(4): 1-32, 14 figures.

McAllister, Don E. 1992. Lead-free, environmentally-friendly fishing weights. Sea Wind, Bulletin of Ocean Voice International, Ottawa, 6(4): 6-7, 2 figures.

McAllister, Don E. 1992. Star sand from southern Japan. Sea Wind, Bulletin of Ocean Voice International, Ottawa 6(4): 10-11, 3 figures.

McAllister, Don E., and Jaime Baquero. 1992. Art live rock - an environmentally friendly alternative to collecting corals and wild live rock for marine aquaria. Sea Wind, Bulletin of Ocean Voice International, Ottawa 6(4): 20-23.

McAllister, Don E. 1992. Marine biodiversity: jewel lanternfish, Lampanyctus crocodilus. Sea Wind, Bulletin of Ocean Voice International, Ottawa 6(4): 25-26, 2 figures.

McAllister, Don E. 1992. Review of: Guide to the marine sport fishes of Atlantic Canada and New England by Brian W. Coad. Sea Wind, Bulletin of Ocean Voice International, Ottawa 6(4): 27-28.

McAllister, Don E. 1992. Saving ocean ecosystems by conserving forests through use of solar energy. Sea Wind, Bulletin of Ocean Voice International, Ottawa 6(4): 2931, 2 figures.

McAllister, Don E., Editor and partial author/Editeur et auteur en partie. 1992. Canadian Biodiversity, Ottawa 2(4): 1-52, numerous text figures; Bulletin canadien de la biodiversité, Ottawa 2(4): 1-52, schémas dans le texte plusieurs. 
McAllister, Don E. 1992. A green path from sea to sea. Canadian Biodiversity, Ottawa 2(4): 17-21, 5 figures; Un sentier de verdure d'un océan à l'autre. Bulletin canadien de la biodiversité, Ottawa 2(4): 14-18, 4 figures.

McAllister, Don E. 1992. A basic biodiversity reference library. Canadian Biodiversity, Ottawa 2(4): 22-28; Une bibliothèque de références sur la biodiversité. Bulletin canadien de la biodiversité, Ottawa 2(4): 19-26.

McAllister, Don E. 1992. Biodiversity distinguished from Biological Resources. Canadian Biodiversity, Ottawa 2(4): 29, 4 figures; Biodiversité ou ressources biologiques? Bulletin canadien de la biodiversité, Ottawa 2(4): 27, 4 figures.

McAllister, Don E. 992. Lead-free fishing weights. Canadian Biodiversity, Ottawa 2(4): 30-31, 4 figures. Pesées sans plomb pour lignes à pêche. Bulletin canadien de la biodiversité, Ottawa 2(4): 28-29, 4 figures.

McAllister, Don E. 1992. Breakthrough in alcohol-producing bacteria - the "alcorobe." A model/lesson for eco-friendly harnessing of microorganisms. Canadian Biodiversity, Ottawa 2(4): 32-35, 1 figure. Une nouvelle bactérie alcooligène: l'alcorobe ou Un modèle, ou même une leçon, d'utilisation écologique de microorganismes. Bulletin canadien de la biodiversité, Ottawa 2(4): 30-33, 1 figures.

McAllister, Don E. 1992. Review of: Tek Talk. A newsletter on traditional ecological knowledge by Canadian Museum of Nature, Ottawa. Canadian Biodiversity, Ottawa 2(4): 41-42. Bulletin canadien de la biodiversité, Ottawa 2(4): 40-41.

McAllister, Don E. 1992. Review of: The nature of southeast Alaska by Rita M. O'Clair, Robert H. Armstrong, and Richard Carstensen. Canadian Biodiversity, Ottawa 2(4): 47-48; Bulletin canadien de la biodiversité, Ottawa 2(4): 47-48.

McAllister, Don E. 1992. Review of: Forestry on the hill by the Canadian Forestry Association, Ottawa; Revue de: Forestry on the hill par l'Association forestière canadienne, Ottawa. Canadian Biodiversity, Ottawa 2(4): 48-49; Bulletin canadien de la biodiversité, Ottawa 2(4): 48-49.

McAllister, Don E. 1992. Review of: The fishes of Alberta by Joseph S. Nelson and Martin J. Paetz. Canadian Biodiversity, Ottawa 2(4): 49-50; Bulletin canadien de la biodiversité, Ottawa 2(4): 49-50.

McAllister, Don E. 1992. Review of: Global Environment Facility, a bulletin on the Global Environment Facility by the World Bank, Washington. Canadian Biodiversity, Ottawa 2(4): 50-51. Bulletin canadien de la biodiversité, Ottawa 2(4): 50-51

McAllister, Don E. 1992. The variety of life on Earth. A presentation to the Standing Committee on the Environment, House of Commons, 23 November 1992. MS, 10 pages.

McAllister, Don E., Editor and partial author. 1993. Sea Wind, Bulletin of Ocean Voice International, Ottawa 7(1): 1-36, 9 figures.

McAllister, Don E. 1993. A pilot biodiversity inventory of the Bahamas. Sea Wind, Bulletin of Ocean Voice International, Ottawa 7(1): 20-21, 1 figure.

McAllister, Don E., Editor and partial author/Editeur et auteur en partie. 1993. Global biodiversity, Ottawa 3(1): 1-48, numerous text figures. La biodiversité mondiale, Ottawa 3(1): 1-48, schémas dans le texte plusieurs.

McAllister, Don E. 1993. Is the hidden tree-fungus partnership in crisis? Global biodiversity, Ottawa 3(1): 32-34, 2 figures: Un vaste réseau souterrain de champignons nourrit les forêts. Cette symbiose est-elle menacée? La biodiversité mondiale, Ottawa 3(1): 33-35, 2 figures.

McAllister, Don E. 1993. Review of: Breeds \& breeders guide to minority livestock breeds in Canada by JoywinFarm Rare Breeds Conservancy Inc., Marmora. Global biodiversity, Ottawa 3(1): 41-42; La biodiversité mondiale, Ottawa 3(1): 42-43

McAllister, Don E. 1993. Review of: 50 simple things your business can do to save the Earth by The Earth Works Group, Berkeley. Global biodiversity, Ottawa 3(1): 43. La biodiversité mondiale, Ottawa 3(1): 44-45.

McAllister, Don E. 1993. Review of: Biology International. The News Magazine of the International Union of Biological Sciences (IUBS), Paris. Global biodiversity, Ottawa 3(1): 44; Revue de: Biology International. Le magazine d'information de l'Union internationale des sciences biologiques (UISB). La biodiversité mondiale, Ottawa 3(1): 45.

McAllister, Don E. 1993. Review of: A global partnership. Canada and the Conventions of the United Nations Conference on Environment and Development (UNCED) by the Standing Committee on the Environment, House of Commons, Canada. Global biodiversity, Ottawa, 3(1): 4445; Revue de: Un partenariat à l'échelle de la planète par le Canada et les Conventions de la Conférence des Nations Unies sur l'environnement et le développement (CNUED). La Biodiversité mondiale, Ottawa 3(1): 45-46.

McAllister, Don E. 1993. Review of: Earth in balance. Ecology and the human spirit by Senator Al Gore. Global biodiversity, Ottawa 3(1): 45. La biodiversité mondiale, Ottawa 3(1): 46-47.

McAllister, Don E., Editor and partial author. 1993. Sea Wind, Bulletin of Ocean Voice International, Ottawa 7(2): 1-36, 19 figures.

McAllister, Don E., and Elisabeth Janssen. 1993. Alternate livelihoods and community fisheries management by Atlantic coast fishers: Options when fish stocks and habitat are exhausted. Sea Wind, Bulletin of Ocean Voice International, Ottawa 7(2): 2-14, 3 figures.

McAllister, Don E. 1993. Power of the pen. Sea Wind, Bulletin of Ocean Voice International, Ottawa 7(2): 24-25.

McAllister, Don E. 1993. Review of: The by-catch of shrimp trawl fisheries by N. L. Andrew and J. G. Pepperell. Sea Wind, Bulletin of Ocean Voice International, Ottawa 7(2): 34-35.

McAllister, Don E. 1993. Review of: Diodon. Newsletter of the Mauritius Marin (sic) Conservation society. Sea Wind, Bulletin of Ocean Voice International, Ottawa 7(2): 34-35.

McAllister, Don E., Editor and partial author/Editeur et auteur en partie). 1993. Global biodiversity, Ottawa, 3(2): 1-48, numerous text figures; La biodiversité mondiale, Ottawa 3(2): 1-48, schémas dans le texte plusieurs.

McAllister, Don E. 1993. How much land is there on Earth? For people? For nature? Global biodiversity, Ottawa 3(2): 6-7, 1 figure; Combien d'espace habitable y a-t-il sur la Terre? La biodiversité mondiale, Ottawa 3(2): 6-7, 1 figure.

Jarzen, David M., and Don E. McAllister, 1993. Love in the plant world benefits the whole world. Global biodiversity, Ottawa 3(2): 15-19, 8 figures. L'amour chez les végétaux profite à tous; La biodiversité mondiale, Ottawa 3(2): 1619, 47, 6 figures.

McAllister, Don E. 1993. Roots of the Earth. Global biodiversity, Ottawa, 3(2): 25-26, 1 figure; Les racines de la Terre. La biodiversité mondiale, Ottawa 3(2): 25-26, 1 figure. 
McAllister, Don E. 1993. Review of: Traditional Ecological Knowledge. Concepts and cases edited by Julian T. Inglis. Global biodiversity, Ottawa 3(2): 37. La biodiversité mondiale, Ottawa 3(2): 37-38.

McAllister, Don E. 1993. Review of: Cumulative Environmental Effects Bulletin by Environment Canada, Hull. Global biodiversity, Ottawa 3(2): 38; Revue de: Bulletin sur les effets environnementaux cumulatifs par Environnement Canada, Hull. La biodiversité mondiale, Ottawa 3(2): 38.

McAllister, Don E. 1993. Review of: Freshwater fish. Canadian Nature Guide by Henry W. Robinson. Global biodiversity, Ottawa 3(2):44-45. La biodiversité mondiale, Ottawa 3(2): 44.

McAllister, Don. 1993. Forests are more than trees. Earthkeeper 3(6): 22-25, 5 figures.

McAllister, Don E., Editor and partial author. 1993. Sea Wind, Bulletin of Ocean Voice International, Ottawa 7(3): 1-36, 17 figures.

McAllister, Don E. 1993. Review of: Indian Ocean tropical fish guide by Helmut Debelius. Sea Wind, Bulletin of Ocean Voice International, Ottawa 7(3): 32-33.

McAllister, Don E. 1993. Review of: Global marine biological diversity edited by Elliot A. Norse. Sea Wind, Bulletin of Ocean Voice International, Ottawa 7(3): 34-35.

McAllister, Don E., Editor and partial author/Editeur et auteur en partie. 1993. Global biodiversity, Ottawa 3(3): 1-46, numerous text figures; La biodiversité mondiale, Ottawa, 3(3): 1-46, schémas dans le texte plusieurs.

McAllister, Don E., and Jane Topping, 1993. A two-billiondollar flood prevention plan. Global biodiversity, Ottawa 3(3): 21-28, 5 figures. L'harmonisation des cycles hydrologiques: un plan de 2 milliards \$ pour prévenir les inondations; La biodiversité mondiale, Ottawa 3(3): 21-28, 5 figures.

McAllister, Don E. 1993. Slippery fish and boat efficiency. Global biodiversity, Ottawa 3(3): 29, 1 figure; Du poisson glissant à des bateaux efficaces. La biodiversité mondiale, Ottawa 3(3): 29, 1 figure.

McAllister, Don E. 1993. Review of: Re-Introduction News by IUCN Species Survival Commission. Global biodiversity, Ottawa,3(3): 36. La biodiversité mondiale, Ottawa 3(3): 36 .

McAllister, Don E. 1993. Review of: Is the extinction crisis real? by Paul Ehrlich. Global biodiversity, Ottawa 3(3): 41; La biodiversité mondiale, Ottawa 3(3): 40-41.

McAllister, Don E. 1993. Review of: The keystone-species concept in ecology and conservation by L. S. Mills, M. S. Soulé, and D. F. Doak. Global biodiversity, Ottawa 3(3): 41-42; La biodiversité mondiale, Ottawa 3(3): 41.

McAllister, Don E., and Alejandro Ansula. 1993. Save our coral reefs. Pagyamanin ang mga bahura. A coral reef care manual. Ocean Voice International, Ottawa. Xv + 126 pages, 99 figures and plates, 1 map.

McAllister, Don E. 1993. Pagyamanin ang mga bahura. Isang manwal ukol sa mga bahura sa Pilipinas at mga kalapit na dagat. Ocean Voice International, Ottawa. viii +89 pages, 85 figures, 1 map.

McAllister, Don E. 1993. The eco-taxa hotspot approach to the conservation of biodiversity: Evolving tools. Association of Systematic Collections Newsletter 21(4): 47-48.

McAllister, Don E., Editor and partial author. 1993. Sea Wind, Bulletin of Ocean Voice International, Ottawa 7(4): 1-32, 11 figures.

McAllister, Don E. 1993. Biodiversity of the ocean depths and its value. Sea Wind, Bulletin of Ocean Voice International, Ottawa 7(4): 13-19.
McAllister, Don E. 1993. Alternative livelihoods for Atlantic coast fishers. 2. More options for diversifications. Sea Wind, Bulletin of Ocean Voice International, Ottawa 7(4): 22.

McAllister, Don E. 1993. Review of; More than a living: Fishing and the social order on a Polynesian atoll by Michael D. Lieber. Sea Wind, Bulletin of Ocean Voice International, Ottawa 7(4): 26-27.

McAllister, Don E., Editor and partial author/Editeur et auteur en partie. 1994. Global biodiversity, Ottawa 3(4): 1-48, numerous text figures; La biodiversité mondiale, Ottawa 3(4): 1-48, schémas dans le texte plusieurs.

McAllister, Don E. 1994. Review of: Issues. Global biodiversity, Ottawa 3(4): 42. La biodiversité mondiale, Ottawa, 3(4): 42.

McAllister, Don E. 1994. Review of: Cognition. Quarterly voice of Canadian Organic Growers, Ottawa. Global biodiversity, Ottawa 3(4): 44. Revue de Cognition. Publication trimestrielle de la Canadian Organic Growers, Ottawa. La biodiversité mondiale, Ottawa 3(4): 4.

McAllister, Don E. 1994. Review of: A comparison of ungrazed and livestock-grazed rock vegetations in Curaçao by Adolpho O. Debro and John A. de Freitas. Global biodiversity, Ottawa,3(4): 44-45; La biodiversité mondiale, Ottawa 3(4): 44-45.

McAllister, Don E. 1994. Review of: Global marine biological diversity edited by Elliott A. Norse. Global biodiversity, Ottawa 3(4): 46-47; La biodiversité mondiale, Ottawa (4): 46-47.

McAllister, Don E. Editor and partial author. 1994. Sea Wind, Bulletin of Ocean Voice International, Ottawa 8(1): 1-36, 12 figures.

McAllister, Don E. and Patricia Almada-Villela, 1994. Coral Reef Fish Specialist Group Report. Sea Wind, Bulletin of Ocean Voice International, Ottawa 8(1): 2-6, 1 figure.

McAllister, Don E. 1994. Review of: Marine Forum. The Quarterly Bulletin of the Canadian Marine Environmental Protection Society. Sea Wind, Bulletin of Ocean Voice International, Ottawa 8(1): 30-31.

McAllister, Don E. 1994. Review of: International Directory of Aquarist Organizations by Rob Huntley and Jaré Sausaman. Sea Wind, Bulletin of Ocean Voice International, Ottawa 8(1): 31-32.

McAllister, Don E., Editor and partial author/Editeur et auteur en partie. 1994. Global biodiversity, Ottawa 4(1): 1-48, numerous text figures; La biodiversité mondiale, Ottawa 4(1):1-48, schémas dans le texte plusieurs.

McAllister, Don E. 1994. Review of: Tales of a shaman's apprentice. An ethnobotanist searches for new medicines in the Amazon rain forest by Mark J. Plotkin. Global biodiversity, Ottawa 4(1): 39-40; La biodiversité mondiale, Ottawa 4(1): 39-40.

McAllister, Don E. 1994. Review of: Kill the cowboy. A battle of mythology in the new west by Sharman Apt Russell. Global biodiversity, Ottawa 4(1): 45-46; La biodiversité mondiale, Ottawa 4(1): 46.

McAllister, Don E. 1994. Review of: The range by Sherm Ewing. Global biodiversity, Ottawa 4(1): 46; La biodiversité mondiale, Ottawa 4(1): 46-47.

McAllister, Don E., Editor and partial author. 1994. Sea Wind, Bulletin of Ocean Voice International, Ottawa 8(2): 1-36, 12 figures.

McAllister, Don E. 1994. Possible causes of the collapse of the Atlantic groundfish fishery: Hypotheses to test, impacts to quanify (sic). Sea Wind, Bulletin of Ocean Voice International, Ottawa 8(2): 2-9, 2 figures. 
McAllister, Don E., Editor and partial author/Editeur et auteur en partie. 1994. Global biodiversity, Ottawa 4(2): 1-48, numerous text figures; La biodiversité mondiale, Ottawa 4(2): 1-48, schémas dans le texte plusieurs.

McAllister, Don E. 1994. Tools for conserving biodiversity: inventories, biosystematics, museums, TAP, RAP, GAP, ETAP, and ATI. A species at a time is too slow! Global biodiversity, Ottawa 4(2): 16-21, 4 figures: Des outils pour la conservation de la biodiversité: inventaires, recherche biosystématique, musées, évaluation taxinomique, évaluation rapide, analyse des écarts, analyse des points chauds écotaxinomiques, inventaire intégral des taxons. L'approche monospécifique: trop lente! La biodiversité mondiale, Ottawa 4(2): 16-21, 4 figures.

McAllister, Don E. 1994. Preserving wood and biodiversity. Global biodiversity, Ottawa 4(2): 22-23, 1 figure; Préserver le bois et la biodiversité. La biodiversité mondiale, Ottawa 4(2): 22-23, 1 figure.

McAllister, Don E. 1994. Review of: Evaluating the carbon sequestration benefits of forestry projects in developing countries by Paul Faeth, Cheryl Cort and Robert Livernash. Global biodiversity, Ottawa 4(2): 43; La biodiversité mondiale, Ottawa 4(2): 43.

McAllister, Don E., Editor and partial author. 1994. Sea Wind, Bulletin of Ocean Voice International, Ottawa 8(3): 1-36, 12 figures.

McAllister, Don E., and Jaime Baquero. 1994. Ornamental fish industry's environmental program. Sea Wind, Bulletin of Ocean Voice International, Ottawa 8(3): 16-18.

McAllister, Don E. 1994. Alternative livelihoods for coastal fishers. 4. Building models of traditional fishing craft. Sea Wind, Bulletin of Ocean Voice International, Ottawa 8(3): 18-24, 3 figures.

McAllister, Don E. 1994. Review of: Life in a fishbowl. Confessions of an aquarium director by Murray Newman. Sea Wind, Bulletin of Ocean Voice International, Ottawa 8(3): 31-32.

McAllister, Don E., Editor and partial author/Editeur et auteur en partie. 1994. Global biodiversity, Ottawa 4(3): 1-48, numerous text figures; La biodiversité mondiale, Ottawa 4(3):1-48, schémas dans le texte plusieurs.

McAllister, Don E. 1994. Review of: Cordillera. A Journal of British Columbia Natural History. Global biodiversity, Ottawa 4(3): 39-40; Revue de: Cordillera. Journal de l'histoire naturelle de la Colombie-Britannique. La biodiversité mondiale, Ottawa 4(3): 39-40.

Alfonso, Noel, and Don E. McAllister. 1994. Biodiversity and the Great Whale Hydroelectric Project. Great Whale Public Review Support Office, Montréal, Great Whale Environmental Assessment: Background Paper 11: vii + 75 pages.

McAllister, Don E., Frederick W., Schueler, Callum Roberts, and Julie P. Hawkins. 1994. Mapping and GIS analysis of the global distribution of coral reef fishes on an equal-area grid, pages 155-175 in Mapping the diversity of nature. Edited by Ronald I. Miller. Chapman \& Hall, London. xvii +218 pages.

\#McAllister, Don E. 1994. Why is biodiversity being lost? Incentives for protecting North American Biodiversity. Different Drummer 1(3): 32-34.

McAllister, Don E., and Gary Spiller. 1994. Trawling and dredging impacts on fish habitat and bycatch in Coastal Zone Canada '94, Cooperation in the Coastal Zone: Conference Proceedings, September 20-23, 1994. Edited by Peter
G. Well and Peter J. Ricketts. World Trade and Convention Centre, Halifax, Nova Scotia, Canada 4: 1709-1718.

Alfonso, Noel, et Don E. McAllister. 1994. La biodiversité et le projet hydroélectrique Grande-Baleine. Dossier-synthèse Number. 11, Évaluation environnementale du projet Grande-Baleine, Bureau de soutien de l'examen public du projet Grande-Baleine, Montréal. vii +81 pages.

McAllister, Don E., Editor and partial author. 1994. Sea Wind, Bulletin of Ocean Voice International, Ottawa 8(4): 1-32, 11 figures.

McAllister, Don E. 1994. Review of: Samudra Report published by Sebastian Mathew. Sea Wind, Bulletin of Ocean Voice International, Ottawa 8(4): 29-30.

\#McAllister, Don E. 1995. Chapter 23. Marine biosystematic/biodiversity priorities: A Canadian perspective, pages 385-393 in Marine and coastal biodiversity in the Tropical Island Pacific Region. Volume 1. Species Systematics and Information Management Priorities. Edited by J. Maragos, M. Peterson, L. Eldridge, J. Bardach, and H. Takeuchi. Program on Environment, East-West Center, Honolulu, Hawaii. 424 pages.

McAllister, Don E., Editor and partial author/Editeur et auteur en partie. 1995. Global biodiversity, Ottawa 4(4): 148 , numerous text figures; La biodiversité mondiale, Ottawa 4(4):1-48, schémas dans le texte plusieurs.

McAllister, Don E. 1995. Marine biodiversity workshop on systematics and databases of tropical Pacific Islands. Global biodiversity, Ottawa 4(4): 25-30, 12 figures; Atelier de travail sur la systématique et les bases de données sur la biodiversité des îles tropicales. La biodiversité mondiale, Ottawa 4(4): 25-30, 12 figures.

McAllister, Don E. 1995. Review of: International Forum: biodiversity, science \& development held by IUBS held in Paris. Global biodiversity, Ottawa 4(4): 32-33; Le forum international sur la biodiversité, les sciences et le développement. La biodiversité mondiale, Ottawa 4(4): 32-33.

McAllister, Don E., Editor and partial author. 1995. Sea Wind, Bulletin of Ocean Voice International, Ottawa 9(1): 1-36, 12 figures.

McAllister, Don E., Editor and partial author/Editeur et auteur en partie. 1995. Global biodiversity, Ottawa 5(1): 1-48, numerous text figures; La biodiversité mondiale, Ottawa 5(1):1-48, schémas dans le texte plusieurs.

McAllister, Don E., Editor and partial author. 1995. Sea Wind, Bulletin of Ocean Voice International, Ottawa 9(2): 1-40, 12 figures.

McAllister, Don E., Editor and partial author/Editeur et auteur en partie. 1995. Global biodiversity, Ottawa 5(2): 1-48, numerous text figures; La biodiversité mondiale, Ottawa 5(2): 1-48, schémas dans le texte plusieurs.

McAllister, Don E. 1995. Consequences of transgressing human laws and nature's laws. Global biodiversity, Ottawa et de la nature. La biodiversité mondiale, Ottawa 5(2):16.

McAllister, Don E. 1995. How will climate change affect taiga underlain by permafrost? Global biodiversity, Ottawa 5(2): 33; Les incidences du changement climatique sur la taïga. La biodiversité mondiale, Ottawa 5(2): 32.

McAllister, Don E., Editor and partial author. 1995. Sea Wind, Bulletin of Ocean Voice International, Ottawa 9(3): $1-36,8$ figures.

McAllister, Don E. 1995. Offshore and deep-sea marine reserves and parks: A major gap in Protected Area Networks. Sea Wind, Bulletin of Ocean Voice International, Ottawa 9(3): 4-14, 2 figures, 2 tables. 
McAllister, Don E. 1995. Advisory body to Biodiversity Convention meets in Paris. Sea Wind, Bulletin of Ocean Voice International, Ottawa 9(3): 18-23.

McAllister, Don E., Editor and partial author/Editeur et auteur en partie. 1995. Global biodiversity, Ottawa 5(3): 1-48, numerous text figures; La biodiversité mondiale, Ottawa 5(3): 1-48, schémas dans le texte plusieurs.

McAllister, Don E. 1995. Review of: IUCN Red List categories by IUCN Species Survival Commission, Gland. Global biodiversity, Ottawa, 5(3): 41-42; La biodiversité mondiale, Ottawa 5(3): 41-42.

McAllister, Don E. 1995. Review of: Good dirt - confessions of a conservationist by David E. Morine. Global biodiversity, Ottawa 5(3): 46; La biodiversité mondiale, Ottawa 5(3): 46.

McAllister, Don E. 1995. The Green School Biodiversity Booklet/Livret sur la Biodiversité pour les Écoles "Vertes". Ocean Voice International, Ottawa. 12 pages, 4 figures.

McAllister, Don E. 1995. First meeting of Advisory Body to the Convention on Biological Diversity: Success in Paris. Global biodiversity, Ottawa 5(3): 19-21; 1 figure. Première réunion fructueuse, à Paris, du conseil consultatif à la Convention sur la diversité biologique. La biodiversité mondiale, Ottawa 5(3): 19-21, 2 figures.

McAllister, Don E. 1995. Review of: Birds to watch 2: The world list of threatened birds. Global biodiversity, Ottawa 5(3): 42; La biodiversité mondiale, Ottawa 5(3): 42.

McAllister, Don E. 1995. Review of: Aerobiologia. Global biodiversity, Ottawa 5(3): 46; La biodiversité mondiale, Ottawa 5(3): 46.

Mosquin, Ted, Peter G. Whiting, and Don E. McAllister. 1995. Canada's biodiversity: the variety of life, its status, economic benefits, conservation costs and unmet needs. Canadian Museum of Nature, Ottawa and Henderson Book Series 23: xxiv + 293 pages, 61 figures [La biodiversité du Canada: État actuel, avantages économiques, coûts de conservation et besoins non satisfaits (disquette)].

McAllister, Don E. 1995. Status of the World Ocean and its Biodiversity. Sea Wind, Bulletin of Ocean Voice International, Ottawa 9(4): 1-72, 7 figures.

McAllister, Don E., Editor and partial author/Editeur et auteur en partie. 1996. Global biodiversity, Ottawa 5(4): $1-48$, numerous text figures. La biodiversité mondiale, Ottawa 5(4): 1-48, schémas dans le texte plusieurs.

McAllister, Don E. 1996. Review of: Watershed sentinel. Environmental News from Georgia Strait and the Islands. Global biodiversity, Ottawa 5(4): 47; La biodiversité mondiale, Ottawa 5(4): 45.

McAllister, Don E., Editor and partial author. 1996. Sea Wind, Bulletin of Ocean Voice International, Ottawa 10(1): 1-31, 6 figures.

Almada-Villela, Patricia, and Don E. McAllister. 1996. IUCN SSC Coral Reef Fish Specialist Group. Sea Wind, Bulletin of Ocean Voice International, Ottawa 10(1): 13-14.

McAllister, Don E., Editor and partial author/Editeur et auteur en partie. 1996. Global biodiversity, Ottawa 6(1): 1-48, numerous text figures; La biodiversité mondiale, Ottawa 6(1): 1-48, schémas dans le texte plusieurs.

McAllister, Don E. 1996. Review of: Biodiversity news. The Smithsonian MAB Program by Smithsonian Institution, Washington. Global biodiversity, Ottawa 6(1): 46; Revue de: Biodiversity news. The Smithsonian MAB Program par Smithsonian Institution, Washington. La biodiversité mondiale, Ottawa 6(1): 46.
McAllister, Don E., Editor and partial author. 1996. Sea Wind, Bulletin of Ocean Voice International, Ottawa 10(2): 1-36, 14 figures.

McAllister, Don E. 1996. Letter to the Editor [About F. Earl Kennedy]. Sea Wind, Bulletin of Ocean Voice International, Ottawa 10(2): 3-4.

McAllister, Don E. 1996. $8^{\text {th }}$ International Coral Reef Symposium in Panama. Sea Wind, Bulletin of Ocean Voice International, Ottawa 10(2): 18-20, 1 figure.

\#McAllister, Don E. 1996. Promoting the future of the marine ornamental industry and coral reefs. OFI (Ornamental Fish International) Journal 16: 16-19.

de Fontaubert, Charlotte, and Don McAllister. 1996. Addressing marine and coastal biodiversity through the CBD process: the "Jakarta Mandate" and beyond. Biodiversity Bulletin, August 1996: 3-5 (www.bionet-us.org/docs/ bb2.pdf).

McAllister, Don E., Editor and partial author. 1996. Sea Wind, Bulletin of Ocean Voice International, Ottawa 10(3): 1-36, 9 figures.

McAllister, Don E. 1996. Review of: IMCRA - An ecosystem based hierarchial classification system for Australia's coastal and marine environments by R. Thackway and I. D. Cresswell. Sea Wind, Bulletin of Ocean Voice International, Ottawa 10(3): 33-34.

McAllister, Don E. 1996. Review of: Beyond Noah's Ark: The evolving role of modern zoological parks and aquariums in field conservation by Michael Hutchins and William G. Conway. Sea Wind, Bulletin of Ocean Voice International, Ottawa 10(3): 35.

McAllister, Don E., Editor and partial author/Editeur et auteur en partie. 1996. Global biodiversity, Ottawa 6(2): 1-48, numerous text figures; La biodiversité mondiale, Ottawa 6(2): 1-48, schémas dans le texte plusieurs.

Schueler, F. W., Julie Hawkins, Callum Roberts, and Don E. McAllister. 1996. Databases and analysis of geographic ranges of coral reef fishes: Virtues of points, grids and polygons. Paper presented at the 8th International Coral Reef Symposium, 24-29 June 1996, Panama City, Panama.

\#McAllister, Don E. 1996. Cyanide collecting: No "quick fixes". OFI (Ornamental Fish International) Journal 17: 1011.

McAllister, Don E. Editor and partial author/Editeur et auteur en partie. 1996. Global biodiversity, Ottawa 6(3): 148 , numerous text figures. La biodiversité mondiale, Ottawa 6(3): 1-48, schémas dans le texte plusieurs.

McAllister, Don E,. 1996. Eco-Products: Eco-foam, duplex printers, and energy efficient computers. Global biodiversity, Ottawa 6(3): 19-20, 2 figures; Mousse écologique, imprimantes duplex, et ordinateurs écoénergétiques; La biodiversité mondiale, Ottawa 6(3): 19-20, 2 figures.

McAllister, Don E. 1996. Report on International Coral Reef Symposium, Panama City, 24-29 June 1996. Global biodiversity, Ottawa 6(3) 5-26; Rapport sur Symposium international sur les Récifs coralliens, 24-29 juin 1996, Panama City, Panama. La biodiversité mondiale, Ottawa 6(3): 5-26.

McAllister, Don E. 1996. Session 2. Ecosystem Management of Fisheries. Introduction. Presentation at the Fourth Session of the Global Biodiversity Forum International: Montreal, August 31-September 1, 1996.

McAllister, Don E., Editor and partial author. 1996. Sea Wind, Bulletin of Ocean Voice International, Ottawa 10(4): 1-36, 19 figures. 
\#McAllister, Don E. 1996. Pagyamanin Ang Mga Bahura. Isang manwal ukol sa mga bahura sa Pilipinas at mga kalapit na dagat. Ocean Voice International, Ottawa and Haribon Foundation for Conservation of Natural Resources, Manila. 89 pages, 88 figures (Tagalog edition of Save Our Coral Reefs).

\#McAllister, Don E. 1996. Atong Panalipdan Ang Gasangan. Ocean Voice International, Ottawa and Haribon Foundation for Conservation of Natural Resources, Manila. 106 pages, 88 figures (Visayan edition of Save Our Coral Reefs).

McAllister, Don E,. Editor and partial author/Editeur et auteur en partie. 1997. Global biodiversity, Ottawa 6(4): 1-48, numerous text figures; La biodiversité mondiale, Ottawa 6(4): 1-48, schémas dans le texte plusieurs.

McAllister, Don E., Editor and partial author/Editeur et auteur en partie. 1997. Global biodiversity, Ottawa 7(1): 148, numerous text figures; La biodiversité mondiale, Ottawa 7(1): 1-48, schémas dans le texte plusieurs.

McAllister, Don E. 1997. The looming threat to the fair sharing of benefits: What can be done to stop it? Global biodiversity, Ottawa 7(1): 32-33; Émergence d'une menace au juste partage des avantages: comment l'enrayer. La biodiversité mondiale, Ottawa 7(1): 32-33.

McAllister, Don E., Editor and partial author). 1997. Sea Wind, Bulletin of Ocean Voice International, Ottawa 11(1): 1-52, 3 figures.

McAllister, Don E. 1997. Table of Contents for SEA WIND. Volumes 6 to 10, 1992-1996. Sea Wind, Bulletin of Ocean Voice International, Ottawa 11(1): 10-51.

McAllister, Don E., Editor and partial author/Editeur et auteur en partie. 1997. Global biodiversity, Ottawa 7(2): 1-64, numerous text figures; La biodiversité mondiale, Ottawa 7(2): 1-64, schémas dans le texte plusieurs.

McAllister, Don E., Editor and partial author. 1997. Sea Wind, Bulletin of Ocean Voice International, Ottawa 11(2): 1-36, 8 figures.

McAllister, Don E. 1997. Review of: Ocean Forests: The diversity and value of kelp forest ecosystems by Carrie Konig. Sea Wind, Bulletin of Ocean Voice International, Ottawa 11(2): 36.

Holthus, Paul, Don McAllister, and Patricia Almada-Villela. 1997. International Year of the Reef. Species, Newsletter of the Species Survival Commission 28: 3 pages, 1 figure (www.iucn.org/themes/ssc/species/spec28/features/ iyor.htm).

McAllister, Don. 1997. MAI: Global power swing to transnationals? Japan Environmental Monitor, 91: unpaginated (June-July)

McAllister, Don E., Andrew L. Hamilton, and Brian Harvey. 1997. Global Freshwater Biodiversity: Striving for the integrity of freshwater ecosystems. Sea Wind, Bulletin of Ocean Voice International, Ottawa 11(3): 1-140, 21 figures.

McAllister, Don E., Editor and partial author/Editeur et auteur en partie. 1997. Global biodiversity, Ottawa 7(3): 1-48, numerous text figures; La biodiversité mondiale, Ottawa 7(3): 1-48, schémas dans le texte plusieurs.

McAllister, Don E., Editor and partial author. 1997. Sea Wind, Bulletin of Ocean Voice International, Ottawa 11(4): 1-36, 8 figures.

McAllister, Don E., Editor and partial author/Editeur et auteur en partie). 1998. Global biodiversity, Ottawa 7(4): 1-48, numerous text figures; La biodiversité mondiale, Ottawa 7(4): 1-48, schémas dans le texte plusieurs.

McAllister, Don E., Andrew L. Hamilton, and Brian Harvey. 1998. Gaps in freshwater ecosystem research. Global biodiversity, Ottawa, 7(4): 12-17, 3 figures: Les lacunes dans la recherche sur les écosystèmes d'eau douce. La biodiversité mondiale, Ottawa 7(4): 12-17, 2 figures.

McAllister, Don E., Editor and partial author. 1998. Sea Wind, Bulletin of Ocean Voice International, Ottawa 12(1): $1-48,8$ figures.

Risk, Michael J., Don E. McAllister, and Linda Behnken, 1998. Conservation of cold- and warm-water seafans: Threatened ancient gorgonian groves. Sea Wind, Bulletin of Ocean Voice International, Ottawa 12(1): 2-21, 4 figures.

Martel, André, and Don E. McAllister. 1998. Mixing mussels: Is introduction a threat to the native Pacific coast blue mussel? Sea Wind, Bulletin of Ocean Voice International, Ottawa 12(1): 26-28, 1 figure.

McAllister, Don E. 1998. Review of: Distribution and status of deep sea corals off Nova Scotia by Heather Breeze. Sea Wind, Bulletin of Ocean Voice International, Ottawa 12(1): 5-46.

McAllister, Don E., Editor and partial author/Editeur et auteur en partie. 1998. Global biodiversity, Ottawa 8(1): 1-32, numerous text figures; La biodiversité mondiale, Ottawa 8(1): 1-32, schémas dans le texte plusieurs.

\#McAllister, Don E. 1998. Status of the world's fresh waters and fishes. A Symposium Honouring Dr. E. J. Crossman. 78th Annual Meeting of the American Society of Ichthyologists and Herpetologists, July 16-July 22, 1998, University of Guelph, Guelph, Ontario. [abstract].

McAllister, Don E., Editor and partial author. 1998. Sea Wind, Bulletin of Ocean Voice International, Ottawa 12(2): 1-40, 11 figures.

McAllister, Don E., Labbish Ning Chao, and C.-T. Shih. 1998. Cyanide fisheries: Where did they start? Sea Wind, Bulletin of Ocean Voice International, Ottawa 12(2): 2-8, 2 figures.

McAllister, Don E. 1998. Oil slicks: A threat to eggs, embryos and larvae of marine fishes and to fisheries? Sea Wind, Bulletin of Ocean Voice International, Ottawa 12(2): 2731, 2 figures.

McAllister, Don E. 1998. Review of: Reefs at Risk. A mapbased indicator of threats to the world's coral reefs by Dirk Bryant. Sea Wind, Bulletin of Ocean Voice International, Ottawa 12(2): 38 .

McAllister, Don E., Editor and partial author/Editeur et auteur en partie. 1998. Global biodiversity, Ottawa 8(2): 1-40, numerous text figures; La biodiversité mondiale, Ottawa 8(2): 1-40, schémas dans le texte plusieurs.

McAllister, Don E. 1998. The lamp shells Phylum Brachiopoda. Global biodiversity, Ottawa 8(2): 14, 1 figure. Les térébratules Phylum Brachiopoda. La biodiversité mondiale, Ottawa 8(2): 14, 1 figure.

McAllister, Don E. 1998. A working bibliography on the toxic effects of cyanide on fishes and corals. Ocean Voice International, Ottawa. 27 pages.

McAllister, Don E. 1998. Status of biodiversity in the planet's fresh and marine waters: The crisis in aquatic biodiversity. Paper presented at ACP-EU Fisheries Research Initiative on Sustainable Use of Aquatic Biodiversity: Data, Tools and Cooperation, EXPO'98, IPIMAR, Lisbon, Portugal, 3-5 September 1998. 5 pages.

McAllister, Don E., Editor and partial author. 1998. Sea Wind, Bulletin of Ocean Voice International, Ottawa 12(3): 1-36, 11 figures.

McAllister, Don E. 1998. Jubilee 2000 - celebrating the Second Millennium by cancelling debts to the world's poorest - Y2K-JB. Sea Wind, Bulletin of Ocean Voice International, Ottawa 12(3): 11-15, 2 figures. 
McAllister, Don E. 1998. Review of: Red Sea Reef Guide by Helmut Debelius. Sea Wind, Bulletin of Ocean Voice International, Ottawa, 12(3): 31-32.

McAllister, Don E. 1998. Review of: Sea cucumbers of British Columbia, southeast Alaska and Puget Sound by Philip Lambert. Sea Wind, Bulletin of Ocean Voice International, Ottawa 12(3): 32-33.

McAllister, Don E. 1998. Review of: Tropical Reef Life $b y$ A. W. Michael. Sea Wind, Bulletin of Ocean Voice International, Ottawa 12(3): 33.

McAllister, Don E. 1998. Review of: Murky waters: Environmental effects of aquaculture in the US by Rebecca Goldburg and Tracy Triplett. Sea Wind, Bulletin of Ocean Voice International, Ottawa 12(3): 33-34.

McAllister, Don E. 1998. Water: The essence of life or a silent threat. The implication of discharge of toxic substances into marine and freshwater environments. Paper presented to the Society of Environmental Toxicology and Chemistry (SETAC), Laurentian Chapter, Ontario, 20 May 1998 (www. atw.ca).

McAllister, Don E., Editor and partial author/Editeur et auteur en partie. 1998. Global biodiversity, Ottawa 8(3): 1-32, numerous text figures; La biodiversité mondiale, Ottawa 8(3): 1-32, schémas dans le texte plusieurs.

McAllister, Don E. 1998. The crises in marine biodiversity and key knowledge. Presentation given at a panel in Pacem in Maribus XXVI [Peace in the Seas], a conference held November 29th to December 3rd, in Halifax, Nova Scotia. 26 pages (www.cacor.ca/mcall.html).

Roberts, Callum M., Julie P. Hawkins, Don E. McAllister, and Frederick W. Schueler. 1998. Distribution and conservation of coral reef fish diversity. Paper presented at the International Society for Reef Studies, France. 5 pages.

McAllister, Don E., Editor and partial author. 1998. Sea Wind, Bulletin of Ocean Voice International, Ottawa 12(4): 1-44, 13 figures.

McAllister, Don E. 1998. Bill Reid: Haida carver, sculptor, jeweller, poet and writer, 1920-1998. Sea Wind, Bulletin of Ocean Voice International, Ottawa 12(4): 7-8.

\#Roberts, Callum M., Julie Hawkins, Alan E. Strong, Frederick W. Schueler, and Don E. McAllister. 1998. The distribution of coral reef fish biodiversity: the climatebiodiversity connection. Paper presented at the Fourth Meeting of the Conference of the Parties to the UN Framework Convention on Climate Change held 2nd-13th November 1998, Buenos Aires, Argentina.

\#Roberts, Callum M., Julie Hawkins, Alan E. Strong, Frederick W. Schueler, and Don E. McAllister. 1998. The distribution of coral reef fish biodiversity: the climatebiodiversity connection. Sea Wind, Bulletin of Ocean Voice International, Ottawa 12(4): 14-28, 8 figures.

McAllister, Don. 1998. Opinion: Trawls are strip-mining the oceans. Environment New Services, 23 December 1998, 3 pages, 2 figures (http://ens.lycos.com/ens/dec98/1998L12-23-03.html).

McAllister, Don E., Editor and partial author/Editeur et auteur en partie. 1999. Global biodiversity, Ottawa 8(4): 1-32, numerous text figures; La biodiversité mondiale, Ottawa 8(4): 1-32, schémas dans le texte plusieurs.

McAllister, Don E., Editor and partial author. 1999. Sea Wind, Bulletin of Ocean Voice International, Ottawa 13(1): 1-40, 6 figures.

McAllister, Don E. 1999. Review of: The Ecology of the Indonesian Seas by Tomas Tomascik, Anmarie Janice Mah,
Anugerah Wontji and Mohammad Kasim Moosa. Sea Wind, Bulletin of Ocean Voice International, Ottawa 13(1): 38-39.

McAllister, Don E. 1999. Review of: The Ecology of the Indonesian Seas by Tomas Tomascik, Anmarie Janice Mah, Anugerah Wontji and Mohammad Kasim Moosa. ISBN 962-593-078-7 Volume VII 642 pages. and ISBN 962-593163-5 Volume VIII 746 pages. The Ecology of Indonesia Series. Garuda Indonesia, Periplus Editions (HK) Ltd, 1997. Reef Encounters 25: 41-42.

McAllister, Don E., J. Baquero, G. Spiller, and R. R. Campbell. 1999. A global trawling ground survey. Report prepared for the Marine Biological Conservation Institute, World Resources Institute and Ocean Voice International, Ottawa. 37 pages.

McAllister, Don E., John Craig, Nick Davidson, and Mary Seddon. 1999. Large dam impacts on freshwater biodiversity. Report prepared for the IUCN - The World Conservation Union as a contribution to the work of the World Commission on Dams, Ottawa. 131 pages, 11 figures, 20 tables.

McAllister, Don E., Editor and partial author. 1999. Sea Wind, Bulletin of Ocean Voice International, Ottawa 13(2): 1-36, 6 figures.

McAllister, Don E. 1999. The orange roughy (Hoplostethus atlanticus), tasty, deep-dwelling and long-lived fish: At risk? Sea Wind, Bulletin of Ocean Voice International, Ottawa 13(2): 2-6, 2 figures.

McAllister, Don E. 1999. The magnificent frigatebird. Sea Wind, Bulletin of Ocean Voice International, Ottawa 13(2): 7, 1 figure.

McAllister, Don E., and Katja Rodriguez. 1999. The Green School Coral Reef Booklet. Ocean Voice International, Ottawa 16 pages, 13 figures.

McAllister, Don E., Ning Labbish Caho (sic), and C.-T. Shih, 1999. Cyanide fisheries: Where did they start? The Secretariat of the Pacific Community Coastal Fisheries Programme, Numea, New Caledonia, Live Reef Fish Information Bulletin, 5 (March 1999): 8 pages. (www.spc.org.nc/ coastfish/News/lrf/5/Lt. RF5.htm).

McAllister, Don E. 1999. Is mariculture the remedy to problems of coral reefs of coastal communities? The Secretariat of the Pacific Community Coastal Fisheries Programme, Numea, New Caledonia, Live Reef Fish Information Bulletin, 5 (March 1999): 4 pages. (www.spc.org.nc/coastfish/ News/lrf/5/9Maricu.htm).

\#McAllister, Don E. 1999. Crisis in marine biodiversity and key knowledge. CACOR (The Canadian Association for the Club of Rome) Proceedings 2(1): 14-27.

McAllister, Don E., (Editor and partial author). 1999. Sea Wind, Bulletin of Ocean Voice International, Ottawa, 13(3): 1-40, 5 figures.

McAllister, Don E,. 1999. Eco-labelling for small-scale fishers and consumers. Sea Wind, Bulletin of Ocean Voice International, Ottawa, 13(3): 2-9, 1 figure.

McAllister, Don E. 1999. Review of: Guide d'identification du phytoplancton marin de l'Estuaire et du Golfe du SaintLaurent, incluant également certains protozoaires by Lyse Bérard-Therriault, Michel Poulin and Luci Bossé. Sea Wind, Bulletin of Ocean Voice International, Ottawa 13(3): 3637.

McAllister, Don E. 1999. Review of: Indian Ocean Reef Guide by Helmut Debelius. Sea Wind, Bulletin of Ocean Voice International, Ottawa 13(3): 38. 
McAllister, Don E. Editor and partial author. 1999. Sea Wind, Bulletin of Ocean Voice International, Ottawa 13(4): 1-36, 4 figures.

\#McAllister, Don E. 2000. Canadian freshwater biodiversity. Essay 12, pages 83-85 in Freshwater ecoregions of North America. A conservation assessment. Edited by Robin A. Abell, David M. Olson, Eric Dinerstein, Patrick T. Hurley, James T. Diggs, William Eichbaum, Stephen Walters, Wesley Wettengel, Tom Allnutt, Colby J. Loucks, and Prashant Hedao. Island Press, Washington, D.C. and Covelo, California. 319 pages.

McAllister, Don E., Editor and partial author. 2000. Sea Wind, Bulletin of Ocean Voice International, Ottawa 14(1): $1-40,11$ figures.

McAllister, Don E. 2000. A hierarchical marine ecosystem classification completed for Canada's West Coast. Sea Wind, Bulletin of Ocean Voice International, Ottawa 14(1): 4-6, 2 figures.

McAllister, Don E. 2000. Review of: Ocean Yearbook 13 by Elisabeth Mann Borgese, Aldo Chirrop Chircop, Moira McConnell, and Joseph R. Morgan. Sea Wind, Bulletin of Ocean Voice International, Ottawa 14(1): 35-39.

McAllister, Don E., Editor and partial author. 2000. Biodiversity (Journal of Life on Earth) 1(1): 1-48 pages, numerous text figures.

McAllister, Don E. 2000. Options in agriculture. Biodiversity (Journal of Life on Earth) 1(1): 2-5, 1 figure, 2 tables.

McAllister, Don E. 2000. Biodiversity awareness: people, museums and the web. Biodiversity (Journal of Life on Earth) 1(1): 38-39.

McAllister, Don. 2000. In favour of farming diversity. Biodiversity (Journal of Life on Earth) 1(1): 40-41, 1 figure.

McAllister, Don E. 2000. Review of: Return to resistance. Breeding crops to reduce pesticide dependence by Raoul A. Robinson. Biodiversity (Journal of Life on Earth) 1(1): 4243.

McAllister, Don E. 2000. Review of: People, plants and patents. The impact of intellectual property rights on trade, plant biodiversity, and rural society by the Crucible Group, Ottawa. Biodiversity (Journal of Life on Earth) 1(1): 43.

McAllister, Don, John Craig, Nick Davidson, Dianne Murray, and Mary Seddon. 2000. Biodiversity impacts of large dams. Prepared for Thematic Review II.1: Dams, ecosystem functions and environmental restoration. Contributing paper on behalf of IUCN - The World Conservation Union to the World Commission on Dams. iv +61 pages., 6 figures, 20 tables (www.dams.org).

McAllister, Don E. 2000. A model framework for a marine ecosystem classification for Canada's West Coast. A discussion paper. Report by Ocean Voice International, Ottawa for Marine Conservation, Western Canada Service Centre, Parks Canada, Vancouver. 90 pages, numerous illustrations.

McAllister, Don E. 2000. Biodiversity in Canadian fresh and marine waters, page 81-105, 5 figures in Biodiversity in Canada: Ecology, ideas, and action. Edited by Stephen Bocking. Broadview Press, Peterborough. xxv +426 pages.

McAllister, Don E., Editor and partial author. 2000. Sea Wind, Bulletin of Ocean Voice International, Ottawa 14(2): $1-36,13$ figures.

McAllister, Don E., and Elisabeth Janssen. 2000. Mounting seaweeds for fun or a livelihood. Sea Wind, Bulletin of Ocean Voice International, Ottawa 14(2): 19-24, 4 figures.

McAllister, Don E. 2000. Review of: Frederick Street. Life and death on Canada's Love Canal by Maude Barlow and Elizabeth May. Sea Wind, Bulletin of Ocean Voice International, Ottawa 14(2): 32-35.
McAllister, Don E., Editor and partial author. 2000. Biodiversity (Journal of Life on Earth) 1(2): 1-48 pages, numerous text figures.

McAllister, Don E. 2000. Pineapple, Ananas comosus. Biodiversity (Journal of Life on Earth) 1(2): 21, 1 figure.

McAllister, Don E. 2000. Review of: Ocean Yearbook 13 Edited by Elisabeth Mann Borgese, Aldo Chirrop Chircop Moira McConnell and Joseph R. Morgan. Biodiversity (Journal of Life on Earth) 1(2): 42-45, 1 figure.

Alfonso, N., and Don E. McAllister. 2000. The distribution of corals on Canada's West Coast. Paper presented in Session 4: Conservation at the 1st International Symposium on Deep Sea Corals: Science of Conservation of Deep Sea Corals, Halifax, Nova Scotia, July 29 to August 3, 2000. 1 page.

McAllister, Don E. Editor and partial author. 2000. Sea Wind, Bulletin of Ocean Voice International, Ottawa 14(3): 1-36, 10 figures.

McAllister, Don E. 2000. Environment and bulk water export under free trade. Sea Wind, Bulletin of Ocean Voice International, Ottawa 14(3): 16-21, 2 figures.

McAllister, Don E. 2000. Fisheries and civil governance. How should fisheries be managed in a democratic society? Sea Wind, Bulletin of Ocean Voice International, Ottawa 14(3): 22-23.

McAllister, Don E. 2000. Review of: Under Southern Seas. The Ecology of Australian Rocky Reefs edited by Neil Andrews. Sea Wind, Bulletin of Ocean Voice International, Ottawa 14(3): 33-34.

McCrae, Ellen, Elvira Maria Alvarado Chacón, Monica Abello, Jaime Baquero, and Don McAllister. 2000. Greater Caribbean Coral Reef Care Manual. Unpublished manuscript, Ocean Voice International, Ottawa and SiwaBan Foundation, Museo del Mar, Fundación Universidad Jorge Tadeo Lozano. 118 pages.

McAllister, Don E., Editor and partial author. 2000. Biodiversity (Journal of Life on Earth) 1(3): 1-48 pages, numerous text figures.

McAllister, Don E. 2000. Review of: The age of spiritual machines. When computers exceed human intelligence by Ray Kurzwill. Biodiversity (Journal of Life on Earth) 1(3): 42-43.

McAllister, Don E., Editor and partial author. 2000. Biodiversity (Journal of Life on Earth) 1(4): 1-48 pages, numerous text figures.

McAllister, Don E., Compiler. 2000. Contents \& Index to Volume 1. Biodiversity (Journal of Life on Earth) 1(4): 4748, endpaper.

McAllister, Don E., Editor and partial author. 2000. Sea Wind, Bulletin of Ocean Voice International, Ottawa 14(4): 1-40, 12 figures.

Burke, Lauretta, Yumiko Kura, Ken Kassem, Carmen Revenga, Mark Spalding, and Don McAllister. 2000. Pilot Analysis of Global Ecosystems (PAGE): Coastal Ecosystems. World Resources Institute, Washington. xii + $5+94$ pages, 16 figures, 20 tables, 18 maps (www.wri.org/ wr2000/coast_page.html) (ISBN 1-56973-458-5).

Coad, Brian W., James D. Reist, Claude B. Renaud, Don E. McAllister, Peter Rask Møller, Noel Alfonso, and Fikret Berkes. 2001. A Field Guide to the Arctic Marine Fishes of Canada. Poster presented at Arctic Ocean Sciences Board, Twentieth Meeting (AOSB-XX), 23-24 April 2001, Iqaluit.

McAllister, Don E., Editor and partial author. 2001. Biodiversity (Journal of Life on Earth) 2(1): 1-48 pages, numerous text figures. 
McAllister, Don E. 2001. The copper redhorse, Moxostoma hubbsi a disappearing Canadian endemic. Biodiversity (Journal of Life on Earth) 2(1): 27-28, 2 figures.

McAllister, Don E., Editor and partial author. 2001. Biodiversity (Journal of Life on Earth) 2(2):1-48 pages, numerous text figures.

Coad, Brian W., James D. Reist, Claude B. Renaud, Don E. McAllister, Peter Rask Møller, Noel Alfonso, and Fikret Berkes. 2001. A Field Guide to the Arctic Marine Fishes of Canada. Poster presented at the Tenth European Congress of Ichthyology - ECI X, Prague, September 3-7, 2001.

Roberts, Callum M., Colin J. McClean, John E. N. Veron, Julie P. Hawkins, Gerald R. Allen, Don E. McAllister, Cristina G. Mittermeier, Frederick W. Schueler, Mark Spalding, Fred Wells, Carly Vynne, and Timothy B. Werner. 2002. Marine biodiversity hotspots and conser- vation priorities for tropical reefs. Science 295: 12801284.

Roberts, Callum M., Colin J. McClean, John E. N. Veron, Julie P. Hawkins, Gerald R. Allen, Don E. McAllister, Cristina G. Mittermeier, Frederick W. Schueler, Mark Spalding, Fred Wells, Carly Vynne, and Timothy B. Werner. 2002. Corrections and clarifications. Science 296: 1027-1028.

McAllister, Don E. 2002. Marine biodiversity of Canada: threats and conservation solutions. Biodiversity (Journal of Life on Earth) 3(1): 11-16, 5 figures [excerpt from: Stephen Bocking. 2000. Biodiversity in Canada. Ecology, ideas, and action. Broadview Press, Peterborough. xxv +426 pages).

Coad, Brian W., and Don E. McAllister. 2002. Dictionary of Ichthyology. First posted 4 September 2002 at www.brian coad.com, maintained by Brian W. Coad and Nicholas P. Coad, Pure Throttle Technologies Inc., Ottawa, Ontario. 